Archive for

Organic Chemistry
Arkivoc 2018, part i, 0-0 to be inserted by editorial office

\title{
Synthesis and properties of seven- to nine-membered ring nitrogen heterocycles. Cyclic amidines and cyclic amidinium salts
}

\author{
Isabel A. Perillo, María C. Caterina, and Alejandra Salerno* \\ Universidad de Buenos Aires, Facultad de Farmacia y Bioquímica, Departamento de Química Orgánica, \\ Junín 956 CABA (1113), Buenos Aires, Argentina \\ E-mail: asalerno@ffyb.uba.ar
}

Received 10-09-2017

Accepted 02-26-2018

Published on line 05-27-2018

\section{Abstract}

Medium-sized ring nitrogen heterocycles are an important class of compound which occurs in a range of natural and synthetic products. This review summarizes the current methods for the synthesis and chemical properties of cyclic amidines and cyclic amidinium salts of medium-sized rings $(n=2-4)$ with a fully saturated backbone.

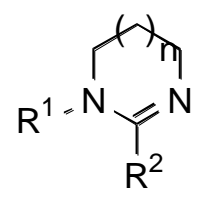

$$
\mathrm{n}=2-4
$$

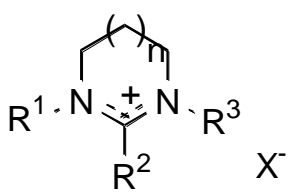

Keywords: Medium-sized nitrogen ring heterocycles, cyclic amidines, cyclic amidinium salts 


\section{Table of Contents}

1. Introduction

2. Synthesis of Cyclic Amidines

2.1. Synthesis of amidines from $1, n$-alkylenediamines

2.2. Synthesis of amidines from $\omega$-aminoamides

3. Chemical Properties of Cyclic Amidines

3.1 Basicity

3.2. Nucleophilic character

3.3. Hydrolysis

3.4. Reduction

4. Synthesis of Cyclic Amidinium Salts

4.1. Synthesis of amidinium salts from acyclic precursors

4.2. Synthesis of amidinium salts from cyclic precursors

5. Chemical Properties of Cyclic Amidinium Salts

5.1. Reaction with Bases

5.1.1. Cyclic amidinium salts as precursors of $\mathrm{N}$-heterocyclic carbenes (NHCs)

5.1.2. Adduct formation

\subsection{Catalytic Activity}

\section{Introduction}

Monocyclic medium-sized ring nitrogen heterocycles are an extremely important class of compounds which occur in a range of natural and synthetic products. The term "medium-sized ring" is usually applied to cyclic compounds having eight to eleven members; ${ }^{1}$ however, seven- and twelve-membered rings are frequently included.

Cyclic amidines (I) represent a heterocyclic core of chemical, biological and pharmacological interest due to the nitrogen function present in these molecules (Figure 1). They are of considerable interest in drug discovery and have been proposed as potential agents for the treatment of several diseases. They are also important as synthetic intermediates.
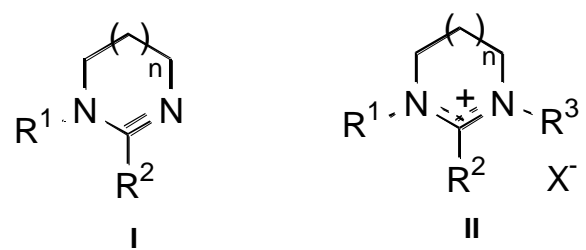
I, $\mathrm{n}=0,1 H-4,5$-dihydroimidazole (imidazoline)
$\mathrm{n}=1,1,4,5,6$-tetrahydropyrimidine
$\mathrm{n}=2,1 \mathrm{H}-4,5,6,7$-tetrahydro-1,3-diazepine
$\mathrm{n}=3,1,4,5,6,7,8$-hexahydro-1,3-diazocine
$\mathrm{n}=4,1 \mathrm{H}-4,5,6,7,8,9$-hexahydro-1,3-diazonine
II, $\mathrm{n}=0,1 \mathrm{H}-4,5$-dihydroimidazolium salt (imidazolinium)
$\mathrm{n}=1,1,4,5,6$-tetrahydropyrimidinium salt
$\mathrm{n}=2,1 \mathrm{H}-4,5,6,7$-tetrahydro-1,3-diazepinium salt
$\mathrm{n}=3,1,4,5,6,7,8$-hexahydro-1,3-diazocinium salt
$\mathrm{n}=4,1 \mathrm{H}-4,5,6,7,8,9$-hexahydro-1,3-diazoninium salt

\section{Figure 1}

Five- and six-membered cyclic amidines, namely imidazolines and tetrahydropyrimidines $(I, n=0,1)$, have been the most studied compounds and are present in many biologically active compounds. ${ }^{2-14}$ However, 
higher homologues, such as $1 \mathrm{H}$-4,5,6,7-tetrahydro-1,3-diazepines and 1,4,5,6,7,8-hexahydro-1,3-diazocines (I, $\mathrm{n}=2,3$ ) have been less studied. It is known that medium-sized rings are generally more difficult to synthesize than their lower counterparts, ${ }^{15-18}$ since the synthetic strategies employed have to overcome unfavorable transannular interactions leading to large enthalpies of activation ${ }^{19,20}$ and the possibility of obtaining products of intramolecular condensation. ${ }^{21}$

Several tetrahydro-1,3-diazepines $(I, n=2)$ are especially interesting compounds due to their pharmacological activities. The antispasmodic, ${ }^{22,23}$ hypoglycemic, ${ }^{24,25}$ antiinflammatory, ${ }^{25}$ diuretic, ${ }^{24,25}$ and antitumor activities $^{26}$ of these compounds have been assessed. More recently, some of these compounds have been investigated as $\mathrm{N}$-methyl-D-aspartate (NMDA) receptor antagonists, ${ }^{27}$ dopamine $\mathrm{D} 4$ receptor $^{28}$ and muscarinic agonists, ${ }^{29}$ as well as for the prophylaxis and protection of human skin against premature aging. ${ }^{30}$

Seven- and eight-membered substituted cyclic amidines are also useful precursors for the synthesis of heterocyclic ring systems as amidinium salts by alkylation, ${ }^{31-33}$ and selectively substituted alkylenediamines by either reduction or alkaline hydrolysis. ${ }^{34-36}$

In recent years, cyclic amidinium salts (CAS) with a fully saturated backbone (II) have attracted a great deal of attention. $1 \mathrm{H}$-Dihydroimidazolium and tetrahydropyrimidinium salts (II, $\mathrm{n}=0,1$ ) have been the most investigated CASs. These salts have been studied in the past century as models of the coenzyme $N^{5}, N^{10}$ methenyltetrahydrofolic acid, which is involved in the biochemical transfer of one carbon unit at the oxidation level of formic acid. ${ }^{37-46}$ CASs II with different patterns of substitution have been employed as synthetic intermediates for the preparation of cyclic and acyclic compounds carrying the alkylenediamine unit $>\mathrm{N}$ $\left.\left(\mathrm{CH}_{2}\right)_{n}-\mathrm{N}<\right)^{42,43}$ Imidazolinium and tetrahydropyrimidinium salts are chemical precursors of $\mathrm{N}$-heterocyclic carbenes (NHCs) that, either alone or as a metal complex, are efficient catalysts for chemical transformation reactions. ${ }^{47-49} 4,5$-Dihydro- $1 \mathrm{H}$-imidazolium salts have also been investigated as surfactants, ${ }^{50}$ due to their potential for chiral molecular recognition, ${ }^{51}$ and as catalysts for several chemical reactions..$^{52,53}$

Unlike the compounds mentioned above, medium-sized cyclic amidinium salts have been less explored. The most important application of these salts is based on their capacity to act as precursors of expanded ring $\mathrm{NHCs}$, which are stronger $\sigma$-donating ligands.

The present review will therefore focus on the synthesis and the main properties of medium-sized cyclic amidines and cyclic amidinium salts (I and II, $n=2-4)$.

\section{Synthesis of Cyclic Amidines}

Synthetic methods of medium-sized cyclic amidines are generally extensions of the methods employed for lower homologous cycles such as imidazolines and tetrahydropyrimidines. Literature data on the higher homologues, 1,3-diazepines, diazocines and diazonines, are scarce.

There are basically two methods for the synthesis of cyclic medium-sized amidines which involve acyclic compounds as precursors (Scheme 1) :

Method A: from $1, n$-alkylenediamines as precursors

Method $B$ : from $\omega$-aminoamides as precursors 
<smiles>CC(C)(C)[C+]CN</smiles><smiles>[R]C1=NCCCN1[Tl]</smiles>

$\mathrm{R}^{1}=\mathrm{H}, \mathrm{Ar}$

$\mathrm{n}=2-4$ cyclodehydration

Method B

\section{$\mathrm{R}_{1} \mathrm{HN} \widehat{\times} \widehat{\mathrm{NHCOR}}^{2}$}

\section{Scheme 1}

113

\subsection{Synthesis of amidines from $1, n$-alkylenediamines (Method A)}

The construction of the amidine nucleus involves the coupling of a $1, n$-diamine with an appropriate condensation partner that provides the C-2 of the amidine ring. The synthesis of tetrahydro-1,3-diazepines and hexahydro-1,3-diazocines from tetramethylenediamines (putrescine) and pentamethylenedimine (cadaverine) was the first class of methods developed in chemistry. Generally, this method was applied to the synthesis of cyclic amidines C-2-substituted with alkyl or aryl groups but without $\mathrm{N}$-substitution.

Cyanides can be an adequate source of C-2. Oxley et al. have described the synthesis of some 2substituted tetrahydrodiazepines 1 in good yields from a mixture of a nitrile and tetramethylenediamine/ tetramethylenediammonium bistoluene- $p$-sulfonate at $200{ }^{\circ} \mathrm{C}$ (Scheme 2). ${ }^{54}$ The practical limitation of this method appears to be that ocurring with the synthesis of tetrahydrodiazepines, since attempts to produce hexahydrodiazocines and diazonines $(I, n=3,4)$ by condensation of penta- and hexamethylenediamines or their salts with cyanides, resulted in a mixture from which no homogeneous solid derivative could be isolated.

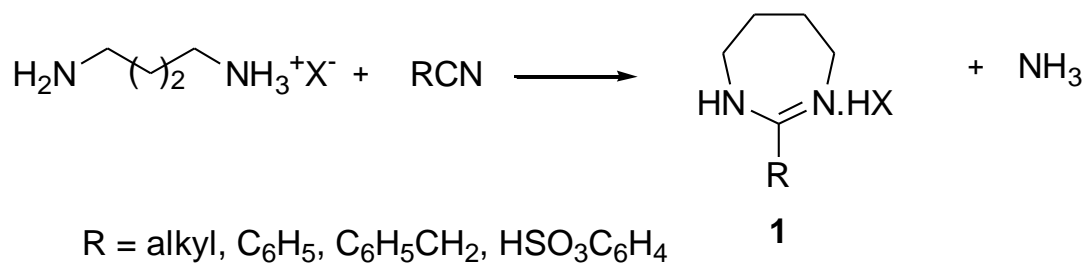

\section{Scheme 2}

Johnson and Woodburn have used more electrophilic nitriles for the synthesis of cyclic amidines of five to seven members. Thus, the authors accomplished the reaction between trifluoroacetonitrile with aliphatic diamines to yield carboxamidines and, where $\mathrm{n}=0-2$, with cyclic amidines as well. ${ }^{55}$ The reactions with tetramethylenediamine yielded carboxamidine as the major product but only $6 \%$ of the cyclic compound, namely 2-trifluoromethyl-4,5,6,7-tetrahydro-1H-1,3-diazepine 2, was isolated (Scheme 3). On the other hand, penta- and hexa-methylenediamine only produced carboxamidines when treated with trifluoroacetonitrile.

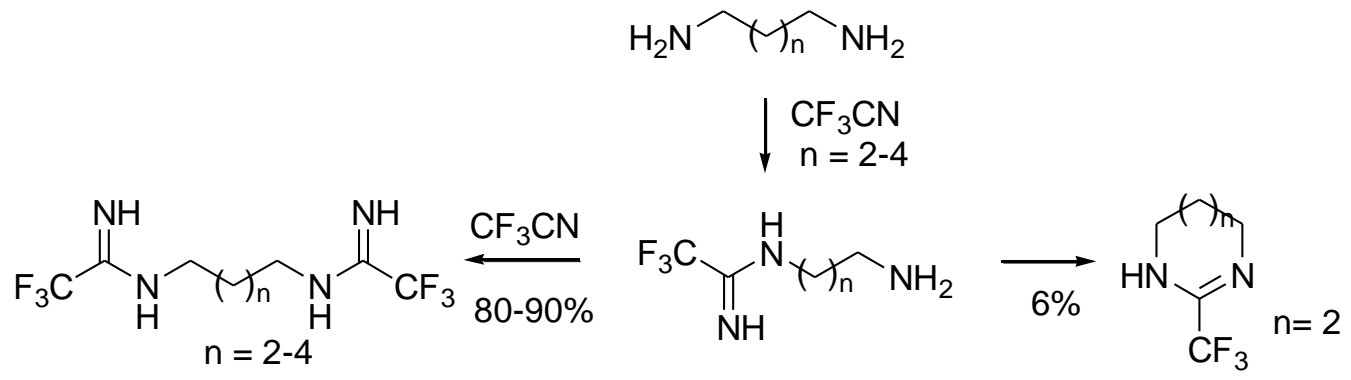

\section{Scheme 3}


Working at high temperatures, 2-o-hydroxyphenyl-1,3-diazepines $\mathbf{3}$ with antihypertensive activity have been obtained from putrescine and 2-methoxybenzonitriles (Scheme 4). ${ }^{56}$

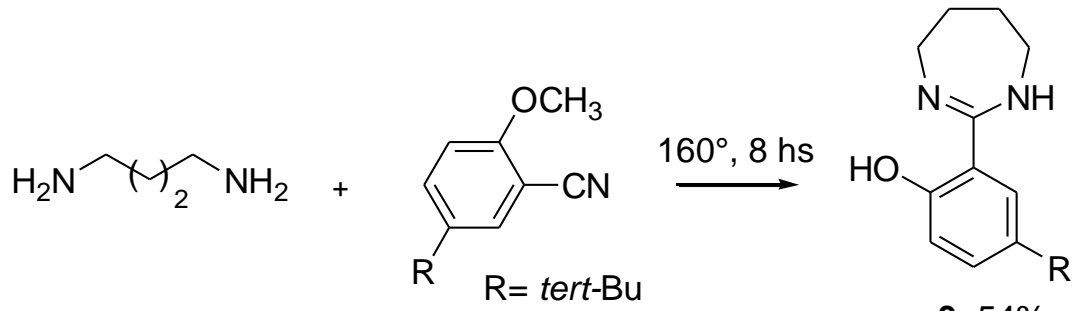

\section{Scheme 4}

3, $54 \%$

The use of catalysts has, in some cases, improved the results of reactions of diamines with nitriles. In 1974, three 1,3-diazepines containing $\alpha$-alkoxybenzyl groups on C-2, with potential hypoglycemic and natriuretic activity, were synthesized using 2-alkoxy-2-arylacetonitriles as source of C-2. ${ }^{57}$ The conversion of the nitrile into the corresponding amidine was readily accomplished by heating the reaction mixture with an excess of diamine using a few drops of $\mathrm{CS}_{2}$ as catalyst.

Forsberg et al. have published the lanthanide(III)-catalyzed addition of amines to nitriles for the construction of amidines. ${ }^{58} \mathrm{Ln}^{3+}$ ions activate nitriles through a predominantly electrostatic ion-dipole interaction. This interaction enhances polarization of the cyano group, thereby facilitating the attack by the nucleophilic amine. The reactions are quite facile and progress to completness (yields 75-95\%) when equimolar amounts of amine and nitrile are heated with $1 \mathrm{~mol} \% \mathrm{Ln}^{3+}$ for $24 \mathrm{~h}$. By means of this strategy, 2methyl, ethyl and phenyl 1H-4,5,6,7-tetrahydro-1,3-diazepines 4 could be synthesized (Scheme 5).

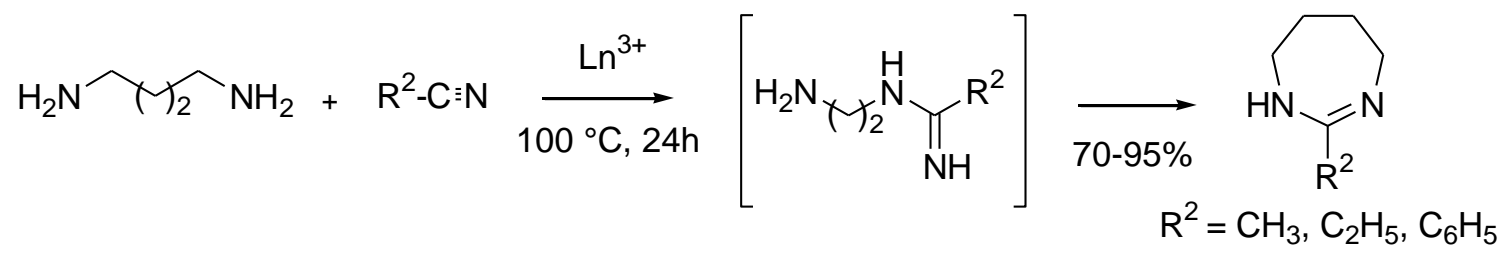

\section{Scheme 5}

As activated equivalents of carboxylic acids, imidic esters (imidates), have been used in the synthesis of cyclic amidines. The reaction of an imidic ester with alkylendiamines generally requires milder reaction conditions than those in which the corresponding nitriles are employed. Sahyun et al. have obtained among other cyclic amidines 2-chloro- and 2-hydroxy-alkyltetrahydro-1,3-diazepines $\mathbf{5 , 6}$ from the corresponding imidic ester hydrochlorides. The compounds were subsequently transformed into esters $\mathbf{7}$ with antispasmodic activity (Scheme 6). ${ }^{22}$ 
<smiles>[R]C(O)C(=[NH2+])OC</smiles><smiles>[R]C(Cl)C(N)OC</smiles><smiles>[3H][3H]</smiles><smiles>NCCCCN</smiles>

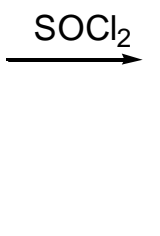

6<smiles>ClCC1=NCCCCN1</smiles>

5

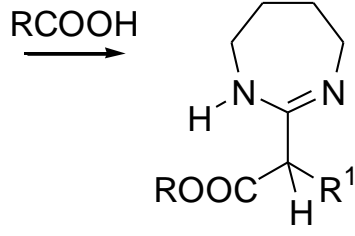

7

\section{Scheme 6}

White et al. have patented the synthesis of a series of five to eight-membered amidines (imidazolines, tetrahydropyrimidines, tetrahydro-1,3-diazepines and hexahydro-1,3-diazocines) from imidic esters with the corresponding diamines. ${ }^{59,60}$

Many of the synthesized compounds have pharmacological activity e.g. diuretic, anti-inflammatory, hypoglycemic and cardiovascular activity. ${ }^{59}$ Miller et al. have obtained other tetrahydrodiazepines and hexahydrodiazocines with antifungal activity using the same methodology. ${ }^{61}$

Another example of the use of an imidic ester as source of C-2 is the formation of the 2-phenyl-1,3diazepines by condensation of 1,4-diaminobutane derivative with methyl benzimidate under moderate reaction conditions. These compounds have been studied as potential dopamine D4 receptor agonists. ${ }^{28}$

More recently, a series of cyclic amidines including a 2,4-diaryl-1,3-diazepines 8 with selective NMDA antagonist activity has been synthesized by reaction of an imidoester with 2-phenylputrescine (Scheme 7). ${ }^{27}$<smiles>NC(CCCNC(=O)OCc1ccccc1)c1ccccc1</smiles><smiles>COc1ccc(C(=N)Oc2ccc(C(F)(F)F)cc2)cc1</smiles>

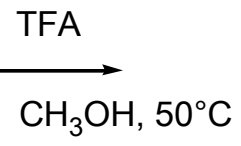

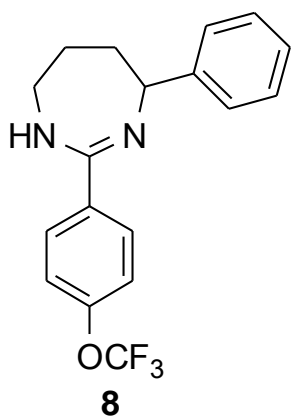

\section{Scheme 7}

The synthesis of cyclic amidines from alkylenediamines and amidinium salts was reported in 1950 by Oxley et al., ${ }^{62}$ who obtained 2-benzyl-1H-4,5,6,7-tetrahydro-1,3-diazepine 9 from N-substituted amidinium salts and putrescine (Scheme 8 ).

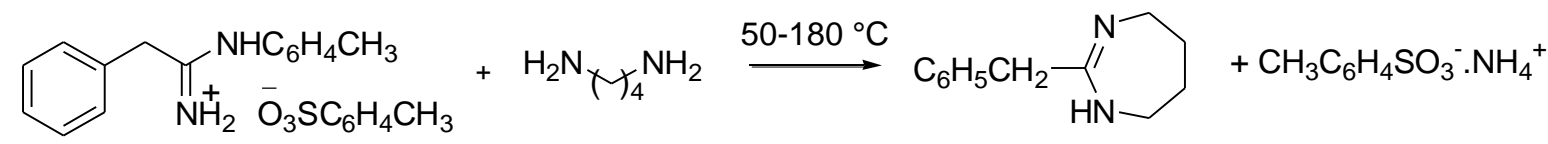

9, $40-55 \%$ 


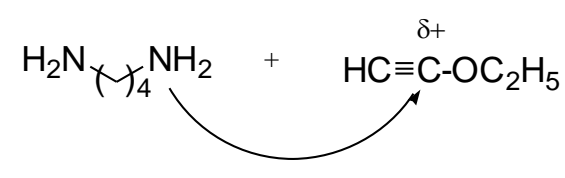

\section{Scheme 9}

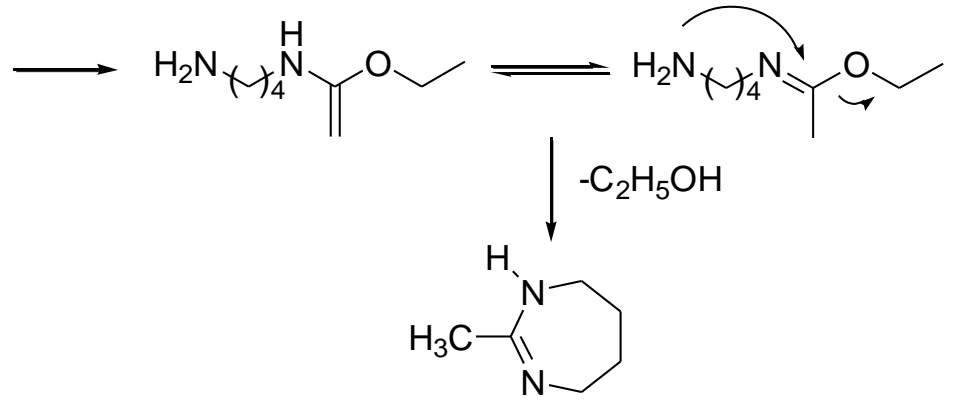

10

Organylthiochloroacetylenes react easily with aliphatic diamines such as putrescine and cadaverine, at low temperatures in benzene, with the formation of 2-(ethylthiomethyl)-1,3-diazepine 11 and the corresponding hexahydrodiazocine (Scheme 10). ${ }^{65}$

$$
\mathrm{CH}_{3} \mathrm{CH}_{2} \mathrm{SC} \equiv \mathrm{CCl}+\mathrm{H}_{2} \mathrm{~N} Y_{\mathrm{R}}^{\mathrm{NH}_{2}} \underset{-\mathrm{HCl}}{\longrightarrow}
$$

\section{Scheme 10}

Thioamides such as $\mathrm{N}$-ethoxycarbonylthioamides have been used to obtain 2-arylderivatives of 4,5,6,7tetrahydro- $1 \mathrm{H}$-1,3-diazepines 12 to obtain moderate yields (Scheme 11 ). ${ }^{66}$

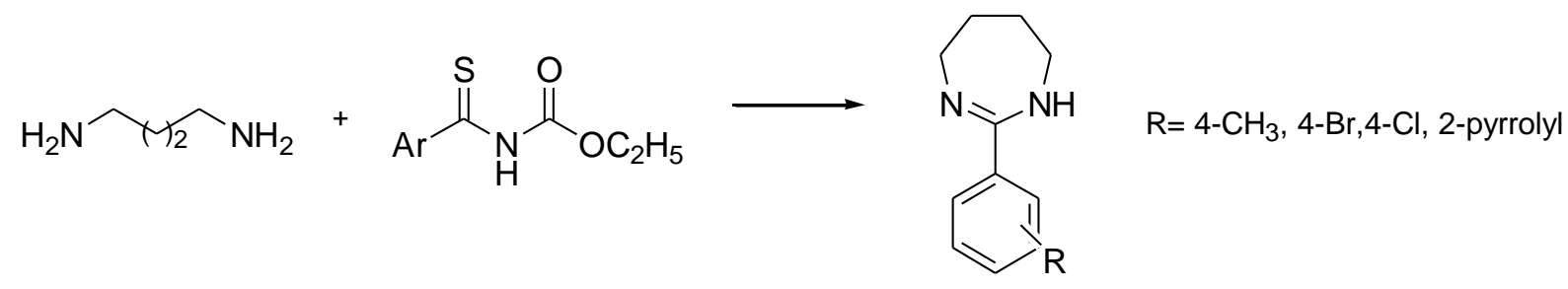

$12,25-57 \%$

\section{Scheme 11}

One of most intensively developing fields in the chemistry of biologically active heterocycles is the synthesis of fluorinated analogues. 4,5,6,7-Tetrahydro-1H-1,3-diazepines 13 bearing a perfluoroalkyl group on C-2 have been obtained by reactions of tetramethylenediamine and a polyfluoroalkylthioamide. ${ }^{67}$ One possible reaction mechanism assumes the intramolecular cyclization of the re-amidation product with the subsequent separation of hydrogen sulfide from the product of cyclization. The reactions have been performed under mild conditions to obtain good yields of the corresponding heterocycles (Scheme 12). 


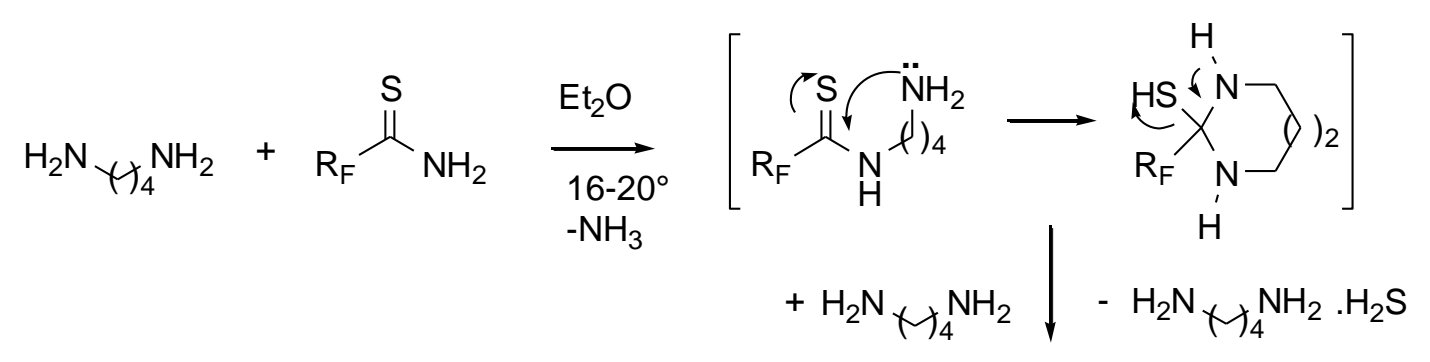

$$
\begin{aligned}
& \mathrm{R}_{\mathrm{F}}=\mathrm{CF}_{3}, \mathrm{HCF}_{2} \mathrm{CF}_{2}, \mathrm{HCF}_{2} \mathrm{CF}_{2} \mathrm{CF}_{2} \mathrm{CF}_{2} \\
& \mathrm{R}_{\mathrm{F}} \mathrm{f}_{\mathrm{HN}}^{\mathrm{N}}
\end{aligned}
$$

\section{Scheme 12}

$13,55-72 \%$

Orthoesters have also been used in the synthesis of cyclic amidines. Plate et al. have synthesized a series of 1,3-diazacycloalkyl carboxaldehyde oxime derivatives with potential muscarinic activities. ${ }^{29}$ Among them, 4,5,6,7-tetrahydro-1,3-diazepine-4-carboxaldehyde oxime 14 was obtained using triethyl orthoformate as reagent (Scheme 13).

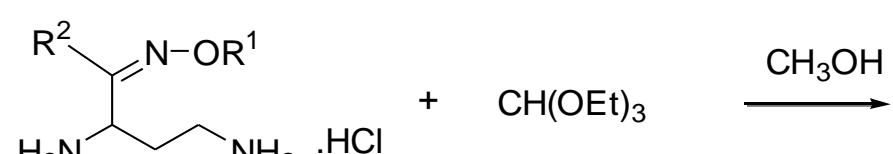

\section{Scheme 13}

In 2009, Wilhelm et al. synthesized a tetrahydro-1,3-diazepine 15 containing a bicyclic core derived from camphor from 1,3-diamino-1,2,2-trimethylcyclopentane, which is a compound easily obtained from camphor that is a very useful material to construct chiral compounds. The method involves the $\mathrm{N}$-alkylation of the camphoric diamine followed by reaction with triethyl orthoformate. ${ }^{68}$
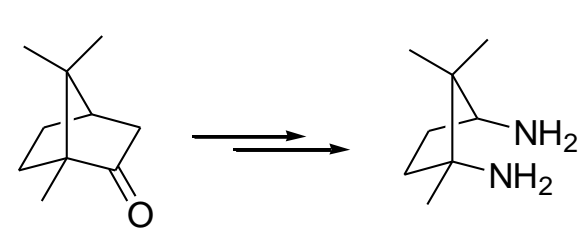
$\mathrm{AcOH} 71 \%$<smiles>CCN1CN2CCC1(C)C(C)(C)C2</smiles>

15
2. $\mathrm{CH}(\mathrm{OEt})_{3}$

1.

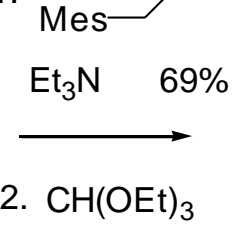

\section{Scheme 14}

Lentzen has patented the synthesis of five- to seven-membered 2-substituted cyclic amidines 16 . The ring closure to the generate the cyclic amidines was accomplished by reactions of C-substituted alkylenediamines with orthoesters (Scheme 15). ${ }^{69}$ 
240

241

242

243

244

245

246<smiles>CC(C)C(C)C(N)C(C)CN</smiles>

\section{Scheme 15}

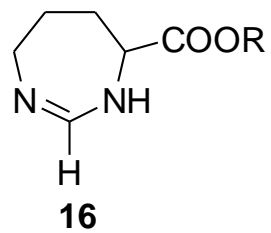

Alkyl halides have also been used as source of C-2. The 3-substituted 5-(chloromethyl)-1,2,4-oxadiazole reacts with putrescine in the presence of sulfur as dehydrogenating agent to yield 2-heteroaryltetrahydro-1,3diazepines 17 (Scheme 16). ${ }^{70,71}$

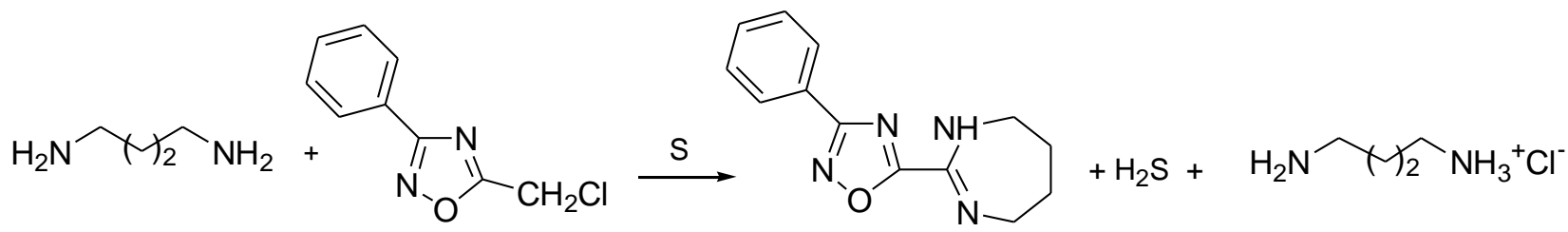

17

\section{Scheme 16}

Bieraugel has studied the carbon unit transfer from cyclic amidinium salts to bifunctional nucleophiles as $\alpha, \omega$-diaminoalkanes. ${ }^{72,34}$ Thus, protonated 4,5,6,7,8,9-hexahydro-1,3-diazonine 18 was obtained using an imidazolinium salt as C-2 donor to hexamethylenediamine (Scheme 17). The process results from the ability of such imidazolinium salt to transfer a formyl equivalent to a variety of nucleophiles. However, the product was only characterized by ${ }^{1} \mathrm{H}-\mathrm{NMR}$ through the presence of the $\mathrm{N}=\mathrm{CH}$ signal at $8.00 \mathrm{ppm}$.

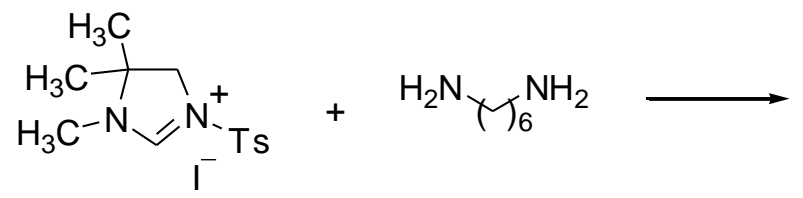

\section{Scheme 17}

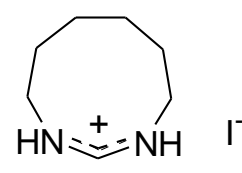

18

Recently Simion et al. have reported an unexpected synthesis of the same diazonine 19 using hexamethylenediamine and dimethylformamide as source of C-2. ${ }^{73}$ The cyclization was explained as a twostep process involving formylation and subsequent intramolecular condensation (Scheme 18).

$$
\mathrm{H}_{2} \mathrm{~N}_{Y} \mathrm{NH}_{6}+\left(\mathrm{CH}_{3}\right)_{2} \mathrm{~N}-\mathrm{CH}=\mathrm{O} \stackrel{\Delta}{\longrightarrow}
$$

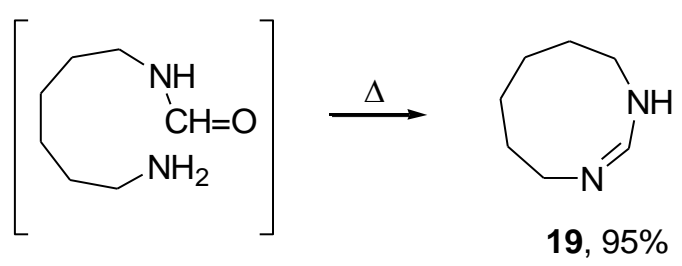

\section{Scheme 18}

The usefulness of this process has been demonstrated through the synthesis of two other nitrogencontaining macroheterocycles (Scheme 19). 
268

269

270

271

272

273

274

275

276

277<smiles>NCCNCCN</smiles>

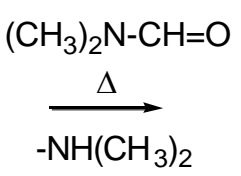

$-\mathrm{H}_{2} \mathrm{O}$<smiles>C1=NCCNCCN1</smiles>

\section{Scheme 19}

\subsection{Synthesis of amidines from $\omega$-aminoamides (Method B)}

This general method involves the cyclodehydration of $N$-aryl- $N^{\prime}$-acylalkylenediamines 20 to the corresponding cyclic amidine by heating with a cyclizing agent. The proposed mechanism is given below. This is a general method for the synthesis of five to eight-membered $\mathrm{N}$-aryl substituted cyclic amidines, and the variations depend on the synthetic route to generate the precursor aminoamide and the cyclizing agent used (Scheme 20). cyclodehydration Method B<smiles>[R]C1=NCCCN1c1ccc([R])cc1</smiles>
$n=0-3$<smiles>[R]OC(=O)NCCCNc1cc[R]cc1</smiles>

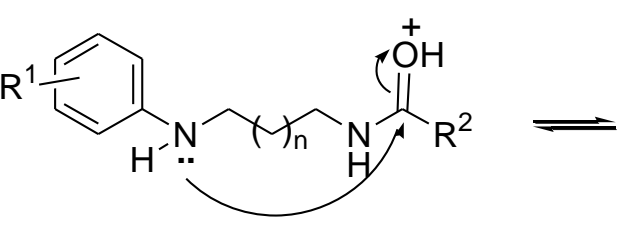<smiles>[R][14c]1ccc([NH+]2CCCNC2([R7])O)cc1</smiles>

\section{Scheme 20}<smiles>[R]C1=NCCCN1c1ccc([R])cc1</smiles><smiles>[R1]c1ccc(N2CCNCC2([R7])C2([2H])CCCC2)cc1</smiles>

Two methods have been employed to synthesize the precursor aminoamides $\mathbf{2 0}$ of tetrahydrodiazepines and hexahydrodiazocines: $\mathrm{N}$-acylation of the corresponding $\mathrm{N}$-arylalkylenediamines $\mathbf{2 1}$ (Method B-1) and from the reaction of $\mathrm{N}$-4-halobutyl or 5-halopentyl benzamides 22 with arylamines (Method B-2) (Scheme 21).

In the first method (Method B-1), the precursor $\omega$-aminoamides can be obtained by aminolysis of the appropriate chloronitrobenzene with tetra- or penta-methylenediamine, followed by benzoylation under Schotten-Baumann conditions. Thus, in 1977 Perillo et al. reported the use of $N$-nitroaryl- $N$ '-aroyltetra- and penta-methylenediamines 23 as precursors of 1,2-diaryl-1,3-diazepines and diazocines having a nitrophenyl substituent on N-1 (Scheme 22). ${ }^{74}$ 
<smiles></smiles>
21

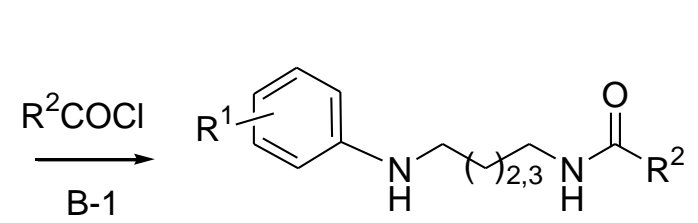

20

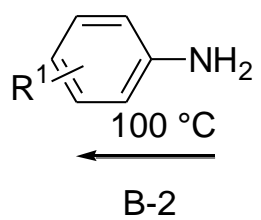

B-2<smiles>[X]CCCNC([R])=O</smiles>

22

\section{Scheme 21}<smiles>[R]C1=NCCCN1c1ccccc1</smiles>

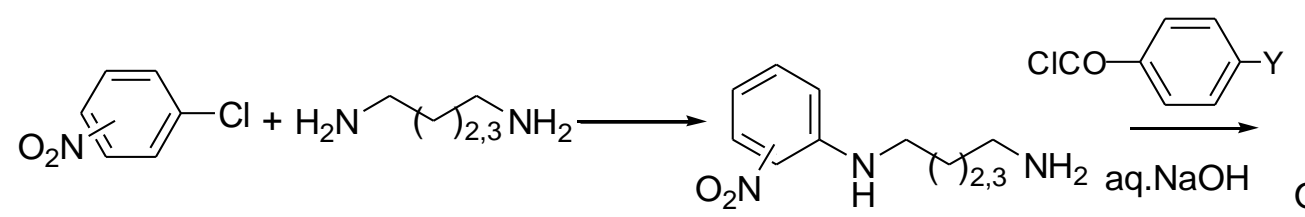

\section{Scheme 22}

However, when the aryl group of the $\mathrm{N}$-arylalkylenediamine is not substituted or when it is substituted with electron donor or slightly electron withdrawing groups, the reaction with acyl chlorides under SchottenBaumann conditions led to the corresponding $N, N^{\prime}$-diacyl derivatives. ${ }^{32}$ Selective monoacylation was achieved using aliphatic carboxylic acid anhydrides working at $0{ }^{\circ} \mathrm{C}$ in a biphasic system $\left(\mathrm{Cl}_{3} \mathrm{CH} / \text { aqueous } \mathrm{Na}_{2} \mathrm{CO}_{3}\right)^{75}$ or working in homogeneous phase with DCM as solvent and TEA as acceptor of hydrogen chloride at $-10^{\circ} \mathrm{C}(55-$ $60 \%)^{32}$

Another suitable synthetic strategy to obtain the precursor aminoamides 20 involves the synthesis of $\mathrm{N}$-4halobutyl or $\mathbf{N}$-5-halopentylbenzamides $\mathbf{2 2}$ as key synthetic intermediates and subsequent reaction with amines (Method B-2). Attempts to obtain the haloalkylamides 22 by acylation of the corresponding $\omega$ haloalkylamines in basic medium have failed, because in such reaction medium intramolecular aminolysis occured. ${ }^{33}$ Conversely, 4-chlorobutyl- and 5-chloropentyl-benzamides could be obtained by reaction of $\mathrm{N}$ benzoylpyrrolidine or piperidine with phosphorus pentachloride by the von Braun reaction (Scheme 23) ${ }^{76}$ The subsequent reaction with arylamines leads to the expected aminoamides $20\left(R^{1}=A r\right){ }^{31,77}$ A drawback of this strategy is that the procedure is restricted to $\mathrm{N}$-acyl derivatives without $\alpha$-hydrogens. ${ }^{76}$

Phosphorus oxychloride, polyphosphoric acid (PPA), ethyl polyphosphate (PPE) and trimethylsilylpolyphosphate (PPSE) have been used as dehydrating agents for the synthesis of $\mathrm{N}$-aryl five- to eightmembered cyclic amidines..$^{35,78-80}$ The synthesis of medium-sized cyclic amidines through the cyclization of aminoamides was first reported in 1977 (Table 1, entries 1-6) ${ }^{74}$ when a series of 1,2-diaryl-1,3-diazepines and diazocines having a nitrophenyl substituent on $\mathrm{N}-1$ were synthesized through the ring closure of the corresponding $N$-nitroaryl- $N^{\prime}$-aroyltetra- and penta-methylenediamines, respectively, employing a chloroform solution of PPE or phosphorus oxychloride as cyclizing agent for the synthesis of diazepines and neat PPE to obtain the corresponding diazocines. Similarly in 2000 Hedrera et al. synthesized 1,3-diazepines employing the same cyclizing agent (Table 1, entries 7-10). ${ }^{33,35}$ 


$$
\prod_{0} \stackrel{\mathrm{Cl}_{5} \mathrm{P}}{\longrightarrow} \underset{\mathrm{X}=\mathrm{Cl}, \mathrm{Br}}{\sim}
$$

\section{Scheme 23}

20

Table 1. Synthesis of $\omega$-aminoamides and their cyclization conditions<smiles>[R]C(=O)NCCCNC1=CC=C[Y]C=C1</smiles>

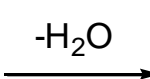<smiles>[R]C1=NCCCN1c1cc[R1]([H])cc1</smiles>

20

20

Entry Synthetic

$\mathrm{R}^{2}$

Cyclization conditions Yield (\%)

Ref.

\begin{tabular}{|c|c|c|c|c|c|c|c|}
\hline 1 & B-1 & $4-\mathrm{NO}_{2}$ & $\mathrm{C}_{6} \mathrm{H}_{5}$ & 2 & $\mathrm{PPE} / \mathrm{CHCl}_{3}, \mathrm{POCl}_{3}$ & 92,76 & 74 \\
\hline 2 & B-1 & $4-\mathrm{NO}_{2}$ & $4-\mathrm{NO}_{2}-\mathrm{C}_{6} \mathrm{H}_{4}$ & 2 & $\mathrm{PPE} / \mathrm{CHCl}_{3}, \mathrm{POCl}_{3}$ & 89,65 & 74 \\
\hline 3 & B-1 & $2-\mathrm{NO}_{2}$ & $\mathrm{C}_{6} \mathrm{H}_{5}$ & 2 & $\mathrm{PPE} / \mathrm{CHCl}_{3}, \mathrm{POCl}_{3}$ & 80,62 & 74 \\
\hline 4 & B-1 & $2-\mathrm{NO}_{2}$ & $4-\mathrm{NO}_{2} \mathrm{C}_{6} \mathrm{H}_{4}$ & 2 & $\mathrm{PPE} / \mathrm{CHCl}_{3}, \mathrm{POCl}_{3}$ & 75,59 & 74 \\
\hline 5 & B-1 & $4-\mathrm{NO}_{2}$ & $\mathrm{C}_{6} \mathrm{H}_{5}$ & 3 & $\mathrm{PPE}, \mathrm{POCl}_{3} / \mathrm{SF}^{\mathrm{a}}$ & 39,24 & 74 \\
\hline 6 & B-1 & $4-\mathrm{NO}_{2}$ & $4-\mathrm{NO}_{2} \mathrm{C}_{6} \mathrm{H}_{4}$ & 3 & $\mathrm{PPE}, \mathrm{POCl}_{3} / \mathrm{SF}$ & 42,30 & 74 \\
\hline 7 & $B-2$ & $\mathrm{H}$ & $\mathrm{C}_{6} \mathrm{H}_{5}$ & 2 & $\mathrm{PPE} / \mathrm{CHCl}_{3}$ & 64 & 33,35 \\
\hline 8 & B-2 & $4-\mathrm{CH}_{3}$ & $\mathrm{C}_{6} \mathrm{H}_{5}$ & 2 & $\mathrm{PPE} / \mathrm{CHCl}_{3}$ & 68 & 33,35 \\
\hline 9 & B-2 & $4-\mathrm{OCH}_{3}$ & $\mathrm{C}_{6} \mathrm{H}_{5}$ & 2 & $\mathrm{PPE} / \mathrm{CHCl}_{3}$ & 60 & 33,35 \\
\hline 10 & B-2 & 4-Cl & $\mathrm{C}_{6} \mathrm{H}_{5}$ & 2 & $\mathrm{PPE} / \mathrm{CHCl}_{3}$ & 55 & 33,35 \\
\hline 11 & B-1 & $2-\mathrm{NO}_{2}$ & $\mathrm{C}_{2} \mathrm{H}_{5}$ & 2 & $\mathrm{PPE} / \mathrm{CHCl}_{3} / \mathrm{MW}^{\mathrm{b}}$ & 93 & 81 \\
\hline 12 & B-1 & $4-B r$ & $\mathrm{C}_{6} \mathrm{H}_{5}$ & 2 & $\mathrm{PPE} / \mathrm{CHCl}_{3} / \mathrm{MW}$ & 89 & 81 \\
\hline 13 & B-1 & $3,4-\left(\mathrm{CH}_{2}\right)_{4}$ & $\mathrm{C}\left(\mathrm{CH}_{3}\right)_{3}$ & 2 & $\mathrm{PPE} / \mathrm{CHCl}_{3} / \mathrm{MW}$ & 84 & 81 \\
\hline 14 & B-1 & $\mathrm{H}$ & $\mathrm{C}_{6} \mathrm{H}_{5}$ & 3 & $\mathrm{PPE} / \mathrm{CHCl}_{3} / \mathrm{MW}$ & 83 & 81 \\
\hline 15 & B-1 & $4-\mathrm{CH}_{3}$ & $\mathrm{C}_{6} \mathrm{H}_{5}$ & 3 & $\mathrm{PPE} / \mathrm{CHCl}_{3} / \mathrm{MW}$ & 79 & 81 \\
\hline 16 & B-1 & $4-\mathrm{Cl}$ & $\mathrm{C}_{2} \mathrm{H}_{5}$ & 2 & $\mathrm{PPE} / \mathrm{CHCl}_{3} / \mathrm{MW} / 100^{\circ}$ & 79 & 75 \\
\hline 17 & B-1 & $4-\mathrm{Cl}$ & $\mathrm{CH}_{3}$ & 2 & $\mathrm{PPE} / \mathrm{CHCl}_{3} / \mathrm{MW} / 100^{\circ}$ & 85 & 75 \\
\hline 18 & B-1 & $4-\mathrm{Cl}$ & iso $-\mathrm{C}_{3} \mathrm{H}_{7}$ & 2 & $\mathrm{PPE} / \mathrm{CHCl}_{3} / \mathrm{MW} / 100^{\circ}$ & 75 & 75 \\
\hline 19 & B-1 & $4-\mathrm{CH}_{3}$ & $\mathrm{CH}_{3}$ & 2 & $\mathrm{PPE} / \mathrm{CHCl}_{3} / \mathrm{MW} / 100^{\circ}$ & 87 & 75 \\
\hline 20 & B-1 & $4-\mathrm{CH}_{3}$ & $\mathrm{C}_{2} \mathrm{H}_{5}$ & 2 & $\mathrm{PPE} / \mathrm{CHCl}_{3} / \mathrm{MW} / 100^{\circ}$ & 71 & 75 \\
\hline 21 & B-1 & $4-\mathrm{CH}_{3}$ & iso $-\mathrm{C}_{3} \mathrm{H}_{7}$ & 2 & $\mathrm{PPE} / \mathrm{CHCl}_{3} / \mathrm{MW} / 100^{\circ}$ & 90 & 75 \\
\hline
\end{tabular}
method 
Table 1. Continued

\begin{tabular}{|c|c|c|c|c|c|c|c|}
\hline Entry & $\begin{array}{c}20 \\
\text { Synthetic } \\
\text { method }\end{array}$ & $\mathrm{R}^{1}$ & $\mathrm{R}^{2}$ & $\mathrm{n}$ & Cyclization conditions & Yield (\%) & Ref. \\
\hline 22 & B-1 & $4-B r$ & iso- $\mathrm{C}_{3} \mathrm{H}_{7}$ & 2 & $\mathrm{PPE} / \mathrm{CHCl}_{3} / \mathrm{MW} / 100^{\circ}$ & 72 & 75 \\
\hline 23 & B-1 & $4-\mathrm{F}$ & iso- $\mathrm{C}_{3} \mathrm{H}_{7}$ & 2 & $\mathrm{PPE} / \mathrm{CHCl}_{3} / \mathrm{MW} / 100^{\circ}$ & 63 & 75 \\
\hline 24 & B-1 & $4-\mathrm{CH}_{3}$ & iso- $\mathrm{C}_{3} \mathrm{H}_{7}$ & 3 & $\mathrm{PPE} / \mathrm{CHCl}_{3} / \mathrm{MW} / 100^{\circ}$ & 42 & 75 \\
\hline 25 & B-1 & $4-\mathrm{CH}_{3}$ & $\mathrm{C}_{2} \mathrm{H}_{5}$ & 3 & $\mathrm{PPSE} / \mathrm{SF}^{\mathrm{b}} / \mathrm{MW} / 90^{\circ}$ & 58 & 82 \\
\hline 26 & B-1 & $4-\mathrm{CH}_{3}$ & iso- $\mathrm{C}_{3} \mathrm{H}_{7}$ & 3 & $\mathrm{PPSE} / \mathrm{SF} / \mathrm{MW} / 90^{\circ}$ & 60 & 82 \\
\hline 27 & B-1 & $4-\mathrm{Cl}$ & $\mathrm{CH}_{3}$ & 3 & 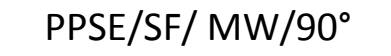 & 50 & 82 \\
\hline 28 & B-1 & $4-\mathrm{Cl}$ & $\mathrm{C}_{2} \mathrm{H}_{5}$ & 3 & $\mathrm{PPSE} / \mathrm{SF} / \mathrm{MW} / 90^{\circ}$ & 61 & 82 \\
\hline 29 & B-1 & $4-\mathrm{Cl}$ & iso- $\mathrm{C}_{3} \mathrm{H}_{7}$ & 3 & $\mathrm{PPSE} / \mathrm{SF} / \mathrm{MW} / 90^{\circ}$ & 84 & 82 \\
\hline 30 & B-1 & $4-\mathrm{Br}$ & $\mathrm{CH}_{3}$ & 3 & PPSE/SF/ MW/90 & 52 & 82 \\
\hline 31 & B-1 & $4-\mathrm{Br}$ & $\mathrm{C}_{2} \mathrm{H}_{5}$ & 3 & PPSE/SF/ MW/90 & 61 & 82 \\
\hline 32 & B-1 & $4-\mathrm{Br}$ & iso- $\mathrm{C}_{3} \mathrm{H}_{7}$ & 3 & $\mathrm{PPSE} / \mathrm{SF} / \mathrm{MW} / 90^{\circ}$ & 81 & 82 \\
\hline 33 & B-1 & $\mathrm{H}$ & $\mathrm{H}$ & 3 & $\mathrm{PPSE} / \mathrm{SF} / \mathrm{MW} / 90^{\circ}$ & 27 & 82 \\
\hline 34 & B-1, B-2 & $\mathrm{H}$ & $\mathrm{C}_{6} \mathrm{H}_{5}$ & 3 & $\mathrm{PPE} / \mathrm{CHCl}_{3} / \mathrm{MW} / 120^{\circ}$ & $95-100$ & 32 \\
\hline 35 & B-1, B-2 & $\mathrm{H}$ & $4-\mathrm{ClC}_{6} \mathrm{H}_{4}$ & 3 & $\mathrm{PPE} / \mathrm{CHCl}_{3} / \mathrm{MW} / 120^{\circ}$ & $95-100$ & 32 \\
\hline 36 & B-1, B-2 & $4-\mathrm{CH}_{3}$ & $\mathrm{C}_{6} \mathrm{H}_{5}$ & 3 & $\mathrm{PPE} / \mathrm{CHCl}_{3} / \mathrm{MW} / 120^{\circ}$ & $95-100$ & 32 \\
\hline 37 & B-1, B-2 & $4-\mathrm{CH}_{3}$ & $4-\mathrm{ClC}_{6} \mathrm{H}_{4}$ & 3 & $\mathrm{PPE} / \mathrm{CHCl}_{3} / \mathrm{MW} / 120^{\circ}$ & $95-100$ & 32 \\
\hline 38 & B-1, B-2 & $4-\mathrm{Cl}$ & $\mathrm{C}_{6} \mathrm{H}_{5}$ & 3 & $\mathrm{PPE} / \mathrm{CHCl}_{3} / \mathrm{MW} / 120^{\circ}$ & $95-100$ & 32 \\
\hline 39 & B-1, B-2 & $3,4-\mathrm{Cl}_{2}$ & $4-\mathrm{ClC}_{6} \mathrm{H}_{4}$ & 3 & $\mathrm{PPE} / \mathrm{CHCl}_{3} / \mathrm{MW} / 120^{\circ}$ & $95-100$ & 32 \\
\hline 40 & B-2 & $4-\mathrm{Cl}$ & $\mathrm{C}_{6} \mathrm{H}_{5}$ & 2 & $\mathrm{PPE} / \mathrm{CHCl}_{3} / \mathrm{MW} / 70^{\circ}$ & 96 & 31 \\
\hline 41 & B-2 & $\mathrm{H}$ & $4-\mathrm{ClC}_{6} \mathrm{H}_{4}$ & 2 & $\mathrm{PPE} / \mathrm{CHCl}_{3} / \mathrm{MW} / 70^{\circ}$ & 95 & 31 \\
\hline 42 & B-2 & $2-\mathrm{Cl}$ & $\mathrm{C}_{6} \mathrm{H}_{5}$ & 2 & $\mathrm{PPE} / \mathrm{CHCl}_{3} / \mathrm{MW} / 70^{\circ}$ & 98 & 31 \\
\hline 43 & B-2 & $\mathrm{H}$ & $2,4-\mathrm{Cl}_{2} \mathrm{C}_{6} \mathrm{H}_{3}$ & 2 & $\mathrm{PPE} / \mathrm{CHCl}_{3} / \mathrm{MW} / 70^{\circ}$ & 96 & 31 \\
\hline 44 & B-2 & $4-\mathrm{Cl}$ & $2,4-\mathrm{Cl}_{2} \mathrm{C}_{6} \mathrm{H}_{3}$ & 2 & $\mathrm{PPE} / \mathrm{CHCl}_{3} / \mathrm{MW} / 70^{\circ}$ & 97 & 31 \\
\hline
\end{tabular}

${ }^{\mathrm{a}} \mathrm{SF}=$ solvent-free conditions. ${ }^{\mathrm{b}} \mathrm{MW}=$ microwave heating.

In general, cyclization reactions usually required long reaction times and high temperatures, resulting in lower product yields in some cases. The traditional methods have been modified to improve their efficiency, optimizing the routes of synthesis with the use of new technologies. Microwave irradiation has emerged as an efficient technique for reagent activation in organic reactions. The remarkable advantages of this methodology are the simple experimental procedures, high yields of products, short reaction times, mild conditions and easy work-ups. In this context, a large number of organic reactions can be carried out under microwave irradiation and compared with classical synthesis procedures. ${ }^{83-87}$

Using this methodology, Orelli et al. have presented a simple and efficient microwave-based protocol for the synthesis of cyclic amidines through an PPE-promoted cyclodehydration of $N$-aryl- $N$ '-acylalkylenediamines, using a modified domestic microwave ${ }^{81}$ (Table 1, entries 11-15). Employing microwave heating and a chloroformic solution of PPE, 1-aryl-1,3-diazepines and diazocines could be obtained with satisfactory (240 W, $2.5 \mathrm{~min}$ and $320 \mathrm{~W}, 6 \mathrm{~min}$ respectively.)

The microwave-assisted ring closure of $N$-aryl- $N^{\prime}$-acyltetramethylenediamine derivatives promoted by PPE allowed the synthesis of 1-aryl-2-alkyl-1,3-diazepines (Table 2, entries 16-23). ${ }^{75}$ The cyclodehydration was 
343

344

345

346

347

348

349

350

351

352

353

354

355

356

357

358

359

360

361

362

363

364

365

366

367

368

369

370

371

372

373

374

carried out in a Monowave 300 monomode reactor. The reactions were completed in $8 \mathrm{~min}$ at $100^{\circ} \mathrm{C}$ with 63 $90 \%$ yield. Under similar conditions, however, considerably lower yields of homologous 1-(4-methylphenyl)-2alkyl-1,3-diazocine were obtained (Table 1, entry 24). ${ }^{75}$ Alternatively, the use of PPSE as cyclodehydrating agent under solvent-free conditions in the microwave-assisted ring closures of $N$-acyl- $N^{\prime}$ arylpentamethylenediamines allowed obtaining acceptable yields of 1-aryl-2-alkyldiazocines (Table 1, entries 25-33). ${ }^{82}$ On the other hand, 1,2-diarylderivatives of 1,3-diazepines and diazocines were obtained by cyclization of either the corresponding $N$-aryl- $N$ '-aroyltetra- or penta- methylenediamine (Table 1 , entries 34$38)^{31,32}$

\section{Chemical Properties of Cyclic Amidines}

\subsection{Basicity}

Cyclic amidines are monobases which, upon protonation on $\mathrm{N}-3$, become cyclic amidiniums salts that are strongly stabilized by mesomeric effect (Scheme 24). ${ }^{35,36,74}$

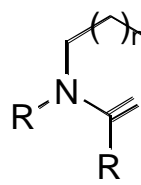<smiles>[R]C1=[N+]([2H])CC2CCN1C2</smiles>

\section{Scheme 24}

Upon comparing the basicity of the seven and eight-membered 1,2-diaryl substituted cyclic amidines $(n=2,3)$ with that of the lower amidine $(n=0,1)$, it was observed that basicity decreases in the order tetrahydropyrimidines $(n=1)>$ tetrahydrodiazepines $(n=2)>$ hexahydrodiazocines $(n=3)>$ imidazolines. ${ }^{35,36,74}$ This phenomenon was attributed to the possible torsion of the seven and eight-membered rings that may result in a less favored delocalization of the amidinium charge, and consequently in a decrease in basicity.

The effects of the sustituents on the N-1 aryl, were analyzed in a series of 1-aryl-2-phenyltetrahydrodiazepines..$^{35,36}$

\subsection{Nucleophilic character}

Like other cyclic amidines, ${ }^{88-91} 1$-substituted tetrahydrodiazepines and hexahydrodiazocines have a strong nucleophilic character due to the $\mathrm{N}-3$ lone electron pair. The reaction with alkyl halides leads to the corresponding resonance-stabilised cyclic amidinium salts $24 . .^{31-33,35}$ Since the reaction is a typical $\mathrm{S}_{\mathrm{N}} 2$ displacement, it is adequate for the introduction of primary alkyl groups (Scheme 25). 
<smiles>[R]CC(C)C1=NCCCN1[R7]</smiles>

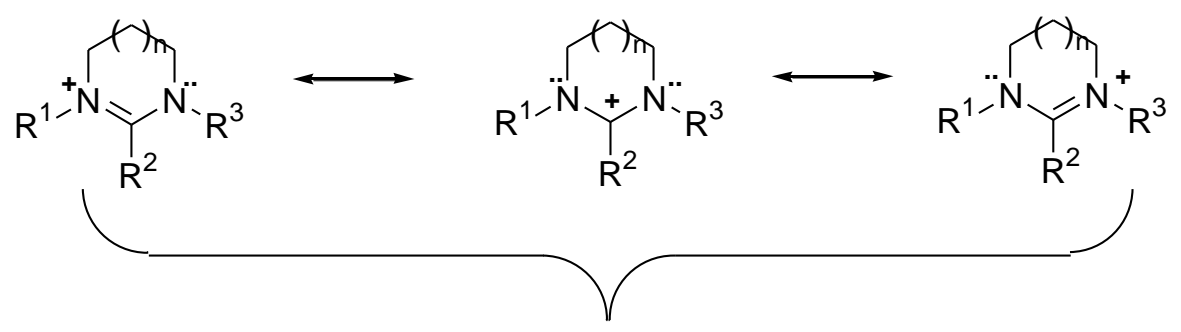

\section{Scheme 25}<smiles></smiles>

\subsection{Hydrolysis}

1,2-Diaryltetrahydrodiazepines and hexahydrodiazocines are resistant to acid hydrolysis due to the high stability of the amidinium ion. ${ }^{36}$ However, due to their amidinic nature, they are hydrolyzed in alkaline solutions affording $\mathrm{N}$-acyl derivatives of the corresponding tetra- and pentamethylenediamines. The observed regioselectivity was analyzed in the light of the stereoelectronic control theory (Scheme 26). ${ }^{35,36}$

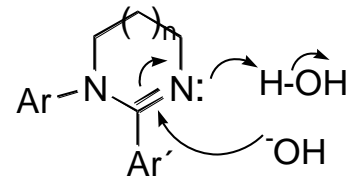

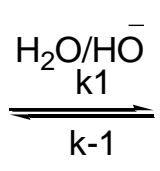<smiles>OC1([Al])NC2CC3CN(Br)CC32N1</smiles><smiles>C=C</smiles><smiles>O=C(Br)NCCCNCBr</smiles>

\section{Scheme 26}

The resistance of cyclic amidines to alkaline hydrolysis depends on the cycle size. A comparison of halflives of 1,2-diaryl derivatives has demonstrated that the degree of stability is: imidazolines $(n=0)<$ tetrahydropyrimidines $(n=1)<$ tetrahydrodiazepines $(n=2)<$ hexahydrodiazocines $(n=3) .{ }^{74}$ The greater stability of the larger rings was attributed to conformational factors that prevent the attack of the nucleophile $\mathrm{OH}^{-}$on $\mathrm{C}-2$.

\subsection{Reduction}

Reduction of 1,2-diaryltetrahydrodiazocines $\mathbf{2 5}$ with borane/THF leads to the regiospecific asymmetrical $N$ aralkyl- $N^{\prime}$-aryltetramethylenediamines 26 with good yields (78-81\%) ${ }^{33,35}$ (Scheme 27). The following reaction mechanism explains the observed regioselectivity (Scheme 27) : 


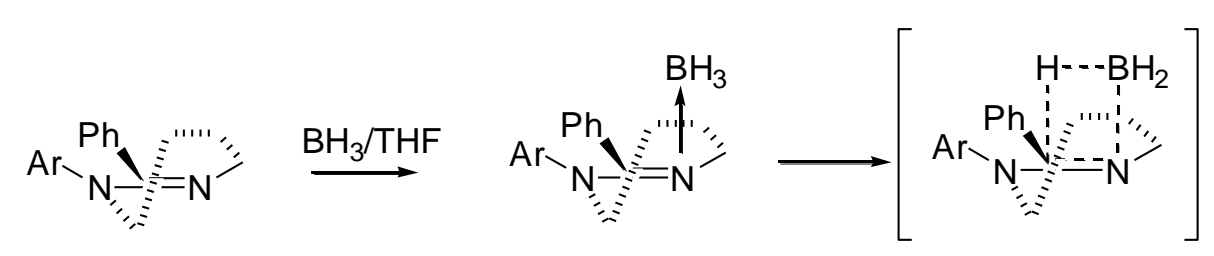

25

\section{Scheme 27}
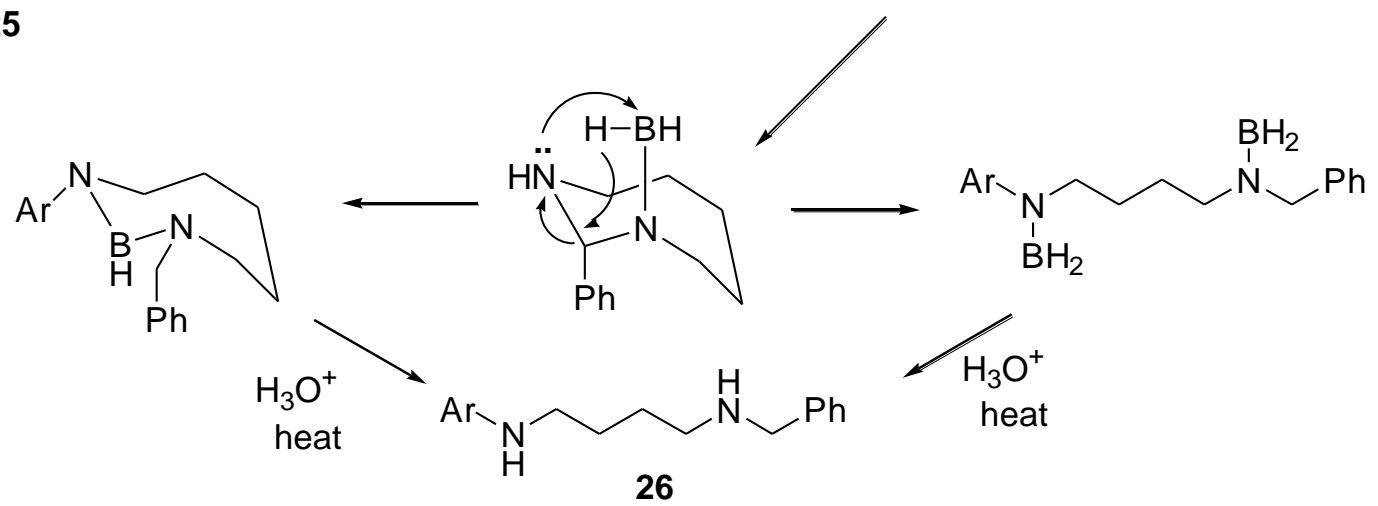

\section{Synthesis of Cyclic Amidinium Salts}

As indicated above (3.2) cyclic amidinium salts are typical salts where the cation is resonance-stabilized and the positive charge can be delocalized either on the nitrogen atoms or on the C-2 (Scheme 25).

As in the case of cyclic amidines, the methods of synthesis for cyclic amidinium salts of medium size, are in general, extensions of the methods employed for lower cyclic amidinium salts. These methods employ both cyclic and acyclic compounds as precursors.

\subsection{Synthesis of amidinium salts from acyclic precursors} The treatment of $\mathbf{N}, \mathbf{N}^{\prime}$-disubstituted $\alpha, \omega$-alkanediamines with trialkyl orthoesters in the presence of a source of protons and anions (ammonium tetrafluoroborate, ammonium hexafluorophosphate, ammonium chloride), leads to the corresponding cyclic amidinium salts. The drawback of this method is that it is not applicable to acid-sensitive substrates. This method employing alkyl orthoformates as C-1 building block is the method of choice for obtaining 2-unsubstituted salts $\left(\mathrm{R}^{2}=\mathrm{H}\right.$, Scheme 28$)$, which are important as NHC precursors.

\section{Scheme 28}

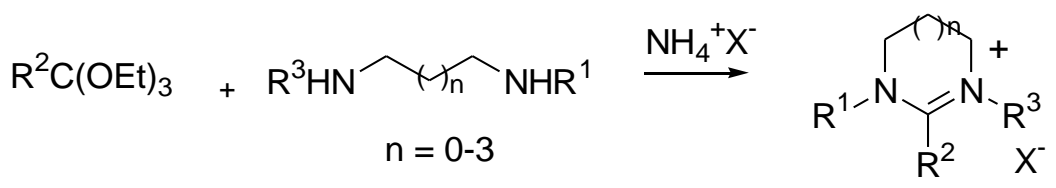

The synthetic routes for obtaining the precursor diamines vary according to the nature of the linking backbone, the nitrogen substituents and the presence of chirality. This issue has been extensively addressed by César et al. $^{92}$

The first report on the synthesis of seven-membered cyclic amidinium salts dates from 1991, when Saba et al. ${ }^{93}$ prepared a series of cyclic amidinium salts by the reaction of trialkyl orthoesters with various $N, N^{\prime}$-dialkyl$\alpha, \omega$-alkanediamines in the presence of ammonium tetrafluoroborate or hexafluorophosphate. Among others, 2-methyl, 2-ethyl and 2-isopropyl substituted tetrahydro-1,3-diazepinium salts were obtained. 
Several diazepinium salts were synthesized later to be used as precursors in the synthesis of sevenmembered $\mathrm{N}$-heterocyclic carbenes (NHC). In this sense, Iglesias et al. have obtained 1,3-dicyclohexyl derivatives $\mathbf{2 7}$ through the reaction of $N, N^{\prime}$-dicyclohexylputrescine with triethyl orthoformate in the presence of ammonium hexafluorophosphate. ${ }^{94}$ The diamine was obtained in high yields by condensation of 1,4diaminobutane followed by reduction of the formed di-imine with sodium borohydride. Overall yields of $70 \%$ after recrystallization were obtained for the formation of the amidinium salt (Scheme 29).

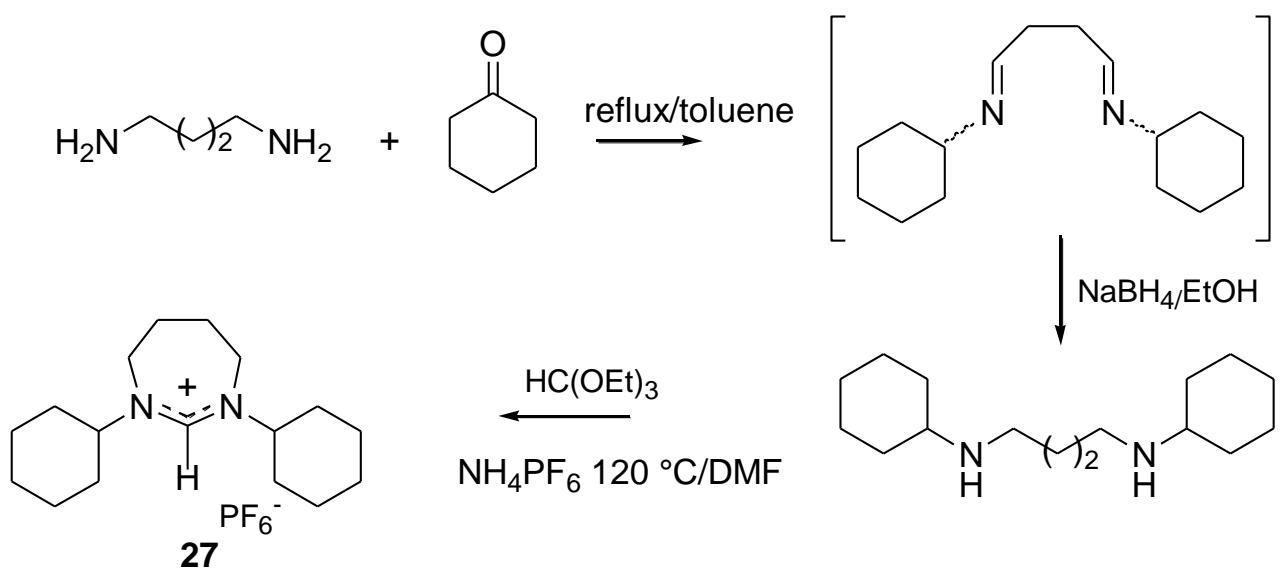

\section{Scheme 29}

Çetinkaya et al. have reported the synthesis of 1,3-dibenzyl and 1,3-diheteroarylmethyl diazepinium salts with good yields. ${ }^{95,96}$ More recently, Wilhelm et al. has reported the synthesis of 1,3-dibenzyl and 1,3-di-( $\alpha$ phenylethyl)diazepinium salts to be employed as organocatalysts ${ }^{97}$ Diazepinium salts embedded in a rigid bicyclic system containing a core derived from camphor 28 were obtained by cyclization of 1,3-diamino-1,2,2trimethylcyclopentane (camphoric diamine) with triethyl orthoformate. ${ }^{68}$ These salts were employed as precursors of enantiopure NHCs (Scheme 30).

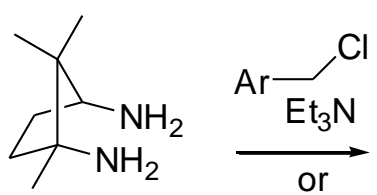

1. $\mathrm{Ar} \longrightarrow \mathrm{O}$

2. $\mathrm{NaBH}_{4}$

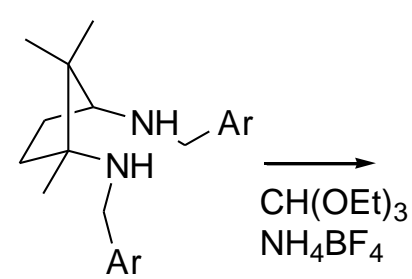

$\mathrm{NH}_{4} \mathrm{BF}_{4}$

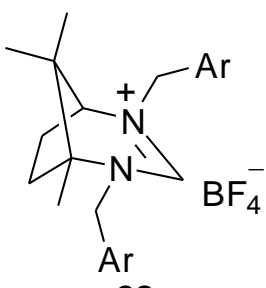

28

\section{Scheme 30}

Employing a similar methodology, Newman et al. have synthetized salts containing aryl groups bearing electron donor groups as precursors of tridentate ligands. ${ }^{98,99}$

In 2005, a method was patented in which orthoesters were used as precursors to prepare cationic polymers bearing cyclic non-aromatic units containing an amidinium group, such as tetrahydrodiazepinium salts, among others. ${ }^{100}$ One strategy to introduce a cyclic amidinium group into a side chain of the polymer is either to start out from a polymer which bears an orthoester group 29, preferably an ethyl orthoester, in the side chain and allow it to react with an $N, N^{\prime}$-dialkyl- $\alpha, \omega$-alkanediamine, or to start out from a polymer which bears the diamine function $\mathbf{3 0}$ in the side chain and allow it to react with an orthoester, preferably an ethyl orthoester (Scheme 31). 

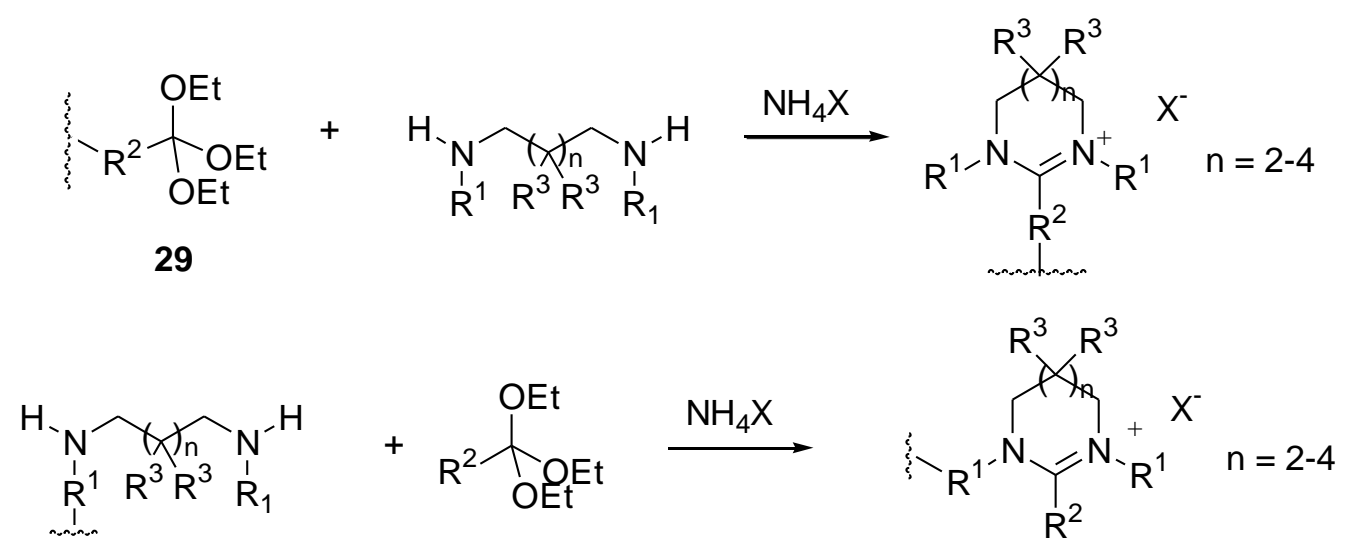

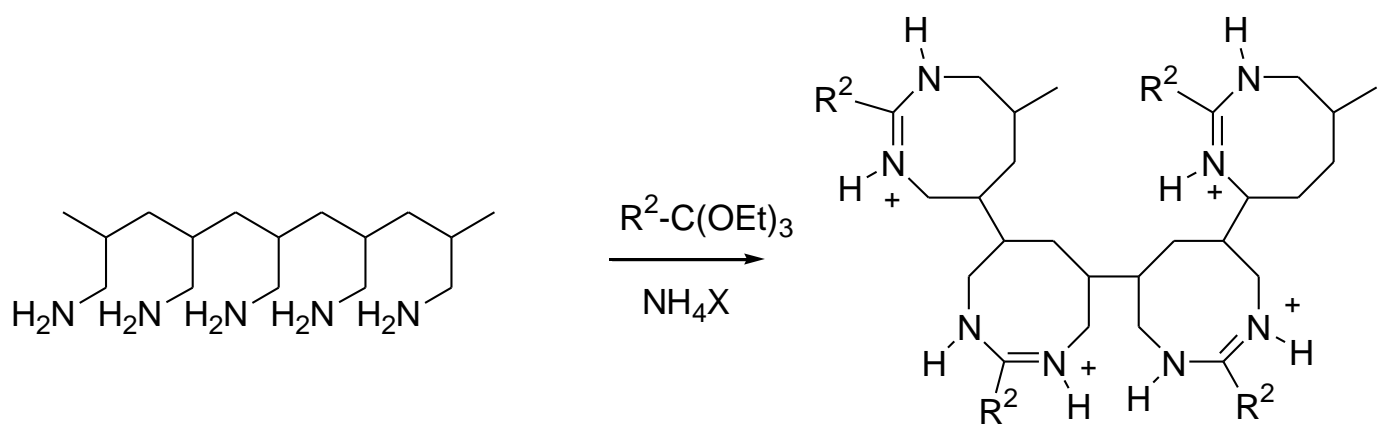

\section{Scheme 31}

In the same patent, polymers in which cyclic amidinium cations are located in the main chain and are linked to it via $\mathrm{C}$ atoms are described. Thus, for example, the reaction of polyamine with an orthoester leads to the formation of polymers $\mathbf{3 1}$ eight-membered rings (cyclic diazocinium ions) in the main chain (Scheme 32 ).

31

\section{Scheme 32}

The reaction of an $\mathbf{N}, \mathbf{N}^{\prime}$-disubstituted amidine with an $\alpha, \boldsymbol{\omega}$-dihalo compound in basic medium has been successfully used for the synthesis of $\mathrm{N}, \mathrm{N}^{\prime}$-diaryl substituted cyclic amidinium salts $\mathbf{3 2}$. From a mechanistic point of view, in the basic medium the deprotonation of the amidine $\mathbf{3 3}$ generates an 1,3-diazaallyl anion, which reacts with a dielectrophile such as the $\alpha, \omega$-dihalo compound (Scheme 33).

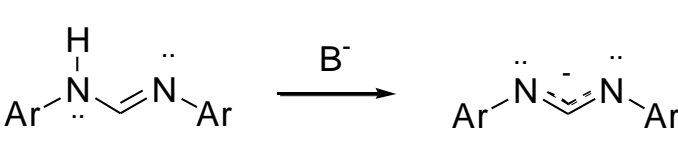

33<smiles>[X]CCCC[Y]</smiles><smiles>[CH]C</smiles>

\section{Scheme 33}

Thus, 2-unsubstituted tetrahydrodiazepinium salts have been synthesized by Cavell through the reaction of the appropriate $N, N^{\prime}$-diarylformamidine with 1,4-diiodobutane in refluxing acetonitrile in the presence of a mild base such as potassium carbonate. ${ }^{101,102}$ The reaction proceeds rapidly for the larger ring sizes and less congested amidines. Formamidine precursors are easily obtained through the reaction of triethyl orthoformate with anilines. This synthetic strategy has been especially employed for $\mathrm{N}$-substituted 
479

480

481

482

483

484

485

486

487

488

489

490

491

492

493

494

495

496

497

498

499

500

501

502

503

504

505

compounds bearing bulky aryl groups (Scheme 34). This method has been used with good results for the synthesis of seven-membered salts with different $\mathrm{N}$-aryl substituents. ${ }^{103-106}$

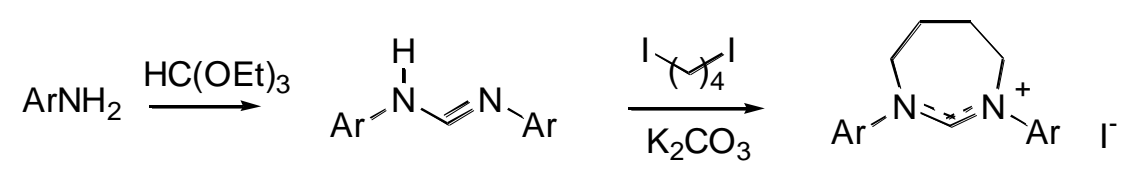

\section{Scheme 34}

Similarly, Nechaev et al. have synthesized six- and seven-membered ring salts with bulky aryl groups by reaction of neat $N, N^{\prime}$-diarylformamidine with 1,4-dibromobutane in the presence of diisopropylethylamine (DIPEA). ${ }^{107,108}$ This method has recently been extended to the synthesis 1,3-dialkyl diazepinium salts. ${ }^{109}$ The formamidine precursor was obtained through the reaction of the alkyl amine with triethyl orthoformate and one equivalent of acetic acid.

Asymmetrically 1,3-substituted rings $\mathbf{3 4}$ may be generated in good to high yields using a formamidine obtained by a step-wise reaction sequence. ${ }^{106}$ During the synthesis of the seven-membered salts containing a pyridine substituent 35 , an alternative ring closure, via of the pyridine ring nitrogen, was observed, giving rise to a novel ionic fused ring product $\mathbf{3 6}$ (Scheme 35 ).

$$
\mathrm{Ar}-\mathrm{NH}_{2}+\mathrm{HC}(\mathrm{OEt})_{3} \underset{-\mathrm{EtOH}}{\stackrel{\mathrm{HCl}}{\longrightarrow}} \quad \mathrm{Ar}^{-} \mathrm{N}_{2} \mathrm{OEt} \stackrel{\mathrm{Ar}^{\prime}-\mathrm{NH}_{2}}{\longrightarrow} \quad \mathrm{Ar}^{-} \mathrm{N}_{2} \stackrel{\mathrm{H}_{-}}{\mathrm{Ar}^{\prime}}
$$

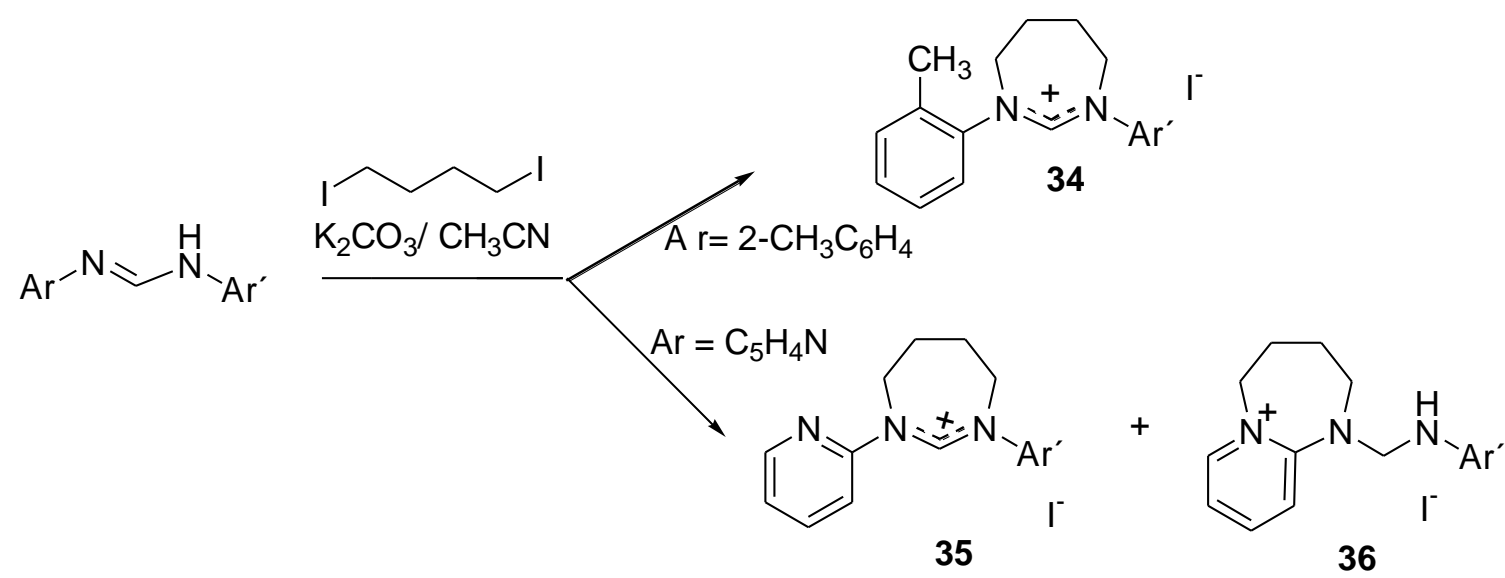

\section{Scheme 35}

Employing this method, Cavell et al. have recently synthesized the first eight-membered cyclic amidinium salts to be employed as NHC precursors (Scheme 36$)$. The reaction was slow but yields were good $(\geq 75 \%) .{ }^{110}$

\section{Scheme 36}
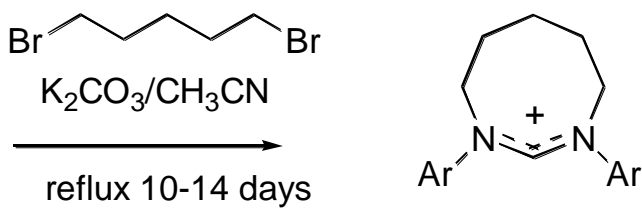

$\mathrm{Br}^{-}$

\subsection{Synthesis of amidinium salts from cyclic precursors}

One of the method involves the dehydrogenation of cyclic aminals (Scheme 37). 
<smiles>[R7]C1NCCCN1[R7]</smiles><smiles>C[CH-]C</smiles>

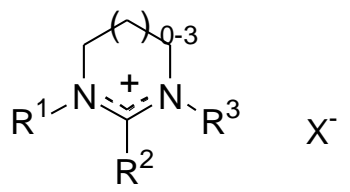

\section{Scheme 37}

The cyclic aminal 37 is commonly obtained from the corresponding $\alpha, \omega$-diaminoalkane and an aldehyde. Formaldehyde is used as C-1 building block to obtain 2-unsubstituted salts. In this method, the cyclization step requires neutral conditions, therefore, it is applicable to acid-sensitive substrates. Probably, for these reasons, Iglesias et al. ${ }^{94}$ have used this route for the synthesis of a seven-membered ring salt $\mathbf{3 8}$ containing a strained 5,6-dioxolane moiety using NBS as a dehydrogenating agent (Scheme 38).
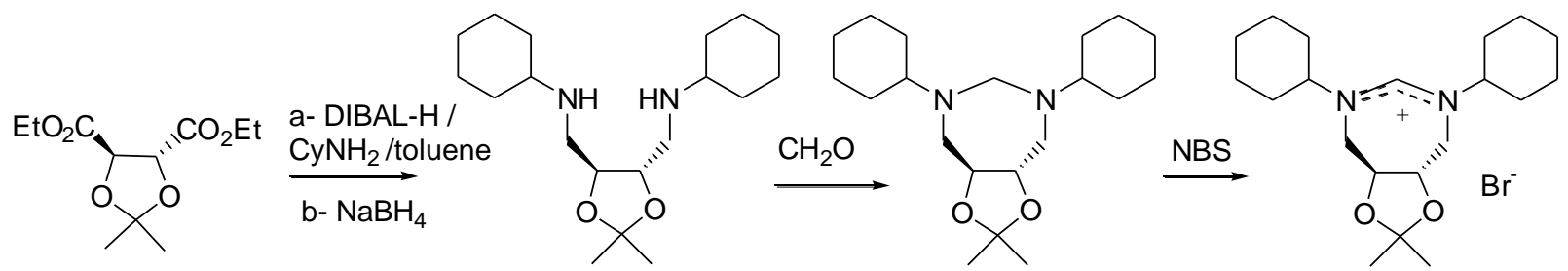

38

\section{Scheme 38}

Similarly, Wilhelm ${ }^{97}$ has reported the synthesis of analogous 1,3-dibenzyl derivatives using NBA as dehydrogenating agent.

The synthesis of 1,3-dibenzyltetrahydrodiazepinium and hexahydrodiazociniun salts 39 through the dehydrogenation of aminals with NBS has recently been described (Scheme 39). ${ }^{31}$<smiles>[R]c1cccc(CN2CCN(Cc3ccccc3)CC2)c1</smiles>

$\mathrm{R}$

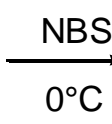

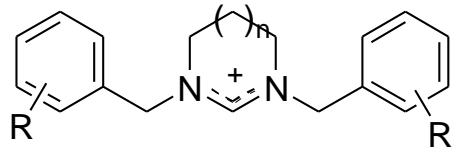

39

$$
\mathrm{n}=2, \mathrm{R}=\mathrm{H} ; 2,3-\mathrm{Cl}_{2} ; 3,4-\mathrm{Cl}_{2} ; 4-\mathrm{Cl}, 4-\mathrm{CH}_{3}
$$$$
\mathrm{n}=3, \mathrm{R}=\mathrm{H} ; 2,3-\mathrm{Cl}_{2} ; 3,4-\mathrm{Cl}_{2} ; 3-\mathrm{Cl}
$$

\section{Scheme 39}

As mentioned in Section 3.2, the alkylation of 1-substituted cyclic amidines affords the corresponding cyclic amidinium salts (Scheme 25). Since the reaction is a typical $S_{N} 2$ displacement, it is adequate for the introduction of primary alkyl groups, being a method of choice for the synthesis of asymmetrically substituted salts. Thus, series of 1,2-diaryl-3-methyl-1H-4,5,6,7-tetrahydro-1,3-diazepinium iodides have been obtained through the reaction of the corresponding diazepines with methyl iodide in anhydrous THF under reflux, obtaining yields of $81-90 \%$ in reaction times of 1-2 h. ${ }^{33,35}$ More recently, this methodology has been optimized by the use of MW irradiation, the reaction times were dramatically decreased (3-6 min) using a Microwave Digestion System in chloroform solution at $90{ }^{\circ} \mathrm{C}$ and $400 \mathrm{~W} .{ }^{31}$ However, when the reaction of 1,3-diazocines were conducted under the same conditions, the major product obtained was the corresponding hexahydrodiazocine hydrohalide. ${ }^{32}$ The protonation of the amidine could be avoided by using a mixture of DCM-DMSO $(10: 1)$ as solvent. Working under reflux conditions with conventional heating, $2-4 \mathrm{~h}$ were required for total 
conversion (71-95\%), while the reaction times were reduced to 6-15 min when MW irradiation was employed (85-96\% yields). ${ }^{31,32}$

Diazepinium salts with a rigid bicyclic system $\mathbf{4 0}$ (camphor skeleton) were also obtained by alkylation (Scheme 40). ${ }^{68}$

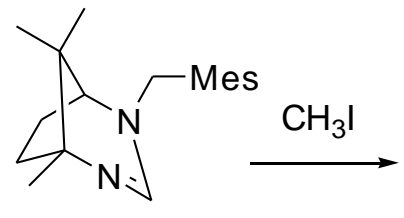

\section{Scheme 40}

\section{Chemical Properties of Cyclic Amidinium Salts}

\subsection{Reaction with bases}

5.1.1 Cyclic amidinium salts as precursors of $\mathrm{N}$-heterocyclic carbenes (NHC). The deprotonation of 2unsubstituted cyclic amidinium salts leads to the generation of NHCs $41 .{ }^{92}$ These compounds are of special interest due to their electron richness. Consequently, they have been widely applied as ligands in transitionmetal catalysts and organometallic chemistry, ${ }^{111-115}$ and as organocatalysts in their own right (Scheme 41). ${ }^{116-}$ 120
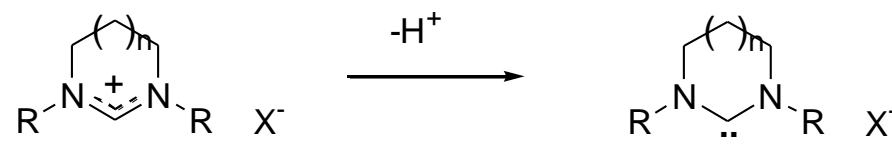

41

\section{Scheme 41}

In particular, tetrahydrodiazepinium salts have been synthesized to be employed as precursors of ring expanded NHCs (RE-NHCs), which are stronger $\sigma$-donating ligands. ${ }^{120}$ Structurally, they also have unique features: the saturated seven-membered ring is flexible, highly twisted, which provides an opportunity to design novel chiral ligands, and of considerable interest due to the large heterocyclic rings with large $\mathrm{N}-\mathrm{C}_{\mathrm{NHC}}-\mathrm{N}$ angles. Key features of these ligands are the presence of an increased basicity and a a high "steric" pressure on the metal center with respect to the more traditional five-membered NHCs.

Different bases have been employed to generate ER-NHCs: $\mathrm{KN}\left(\mathrm{SiMe}_{3}\right)_{2}$ (potassium hexamethyldisilylamide, KHMDS) in $\mathrm{THF} ;{ }^{101-103,106,109,121} \mathrm{LiN}(\mathrm{PPr})_{2}$ (lithium diisopropylamide, LDA) in toluene, ${ }^{101} \mathrm{t}$-BuOK in water/DMF, ${ }^{96,104,105,122} \mathrm{Ag}_{2} \mathrm{O}$ (silver oxide) in $\mathrm{DCM}^{102,107}$ and potassium carbonate. ${ }^{95}$

In some cases, seven-membered free carbenes have been isolated and characterized. ${ }^{102,108,121}$ However, they are generally obtained as metal complexes by direct reaction of the in situ generated carbenes with suitable metal salts. Thus, the generation of Pd-containing complexes have been reported ${ }^{95,96,105,122}$ Other complexes with $\mathrm{Pt}^{104} \mathrm{Au}^{123} \mathrm{Rh}$ and $\mathrm{Ir}^{98,103,106,109}$ have also been reported. Seven-membered NHC complexes of $\mathrm{Cu}$ and Pd have been obtained by transmetallation of the corresponding NHC-Ag (I) complex with suitable metal salts. ${ }^{107,108}$ 
573

574

575

576

577

578

579

580

581

582

583

584

585

586

587

588

589

The use of seven-NHC metal complexes in catalytic transformations have provided encouraging results. The first example has been reported by Cetinkaya et al., who demonstrated that in situ generated 1,3dibenzyltetrahydrodiazepin-2-ylidene palladium complexes are very effective in Suzuki-Miyaura coupling reactions of deactivated aryl chlorides. ${ }^{95}$ Since then, seven-membered NHC complexes have been tested for catalytic transformations such as the Heck type cross-coupling, ${ }^{96,105,122}$ Suzuki type reactions, ${ }^{10,99}$ hydration of internal alkynes, ${ }^{123}$ hydrosilylation, ${ }^{99,104}$ catalytic hydrogenation ${ }^{106}$ and transfer hydrogenation. ${ }^{124,125}$

The important results achieved with complexes bearing expanded ring NHC ancillary ligands in catalytic transformations have been attributed to the strong binding of the electron-rich carbene to the metal center that helps the metal retain its ligand, which provides the compound a longer catalyst life time, thus affording enhanced activity ${ }^{106,126}$

Cavell et al. have reported the synthesis of the first eight-membered ring (diazocanylidene) NHCs 43 (8NHCs) through the reaction of the corresponding cyclic amidinium salt 44 with KHMDS. ${ }^{110}$ In general, the free RE-NHCs could be isolated, and in one case, the molecular structure was elucidated. Rh complexes 45, 46 have been formed through the treatment of the in situ formed free carbene with the appropriate Rh precursor complex. Silver complexes $\mathbf{4 7}$ have been prepared through direct reaction of $\mathrm{Ag}_{2} \mathrm{O}$ with the diazocanylidinium salts (Scheme 42).

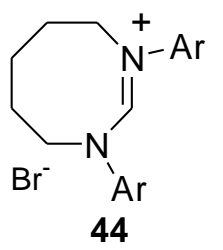

$\downarrow \mathrm{Ag}_{2} \mathrm{O}$

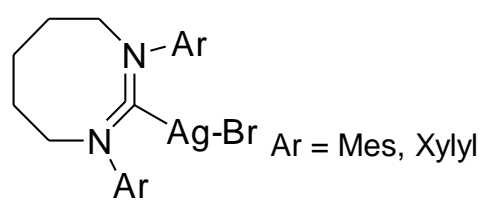

47

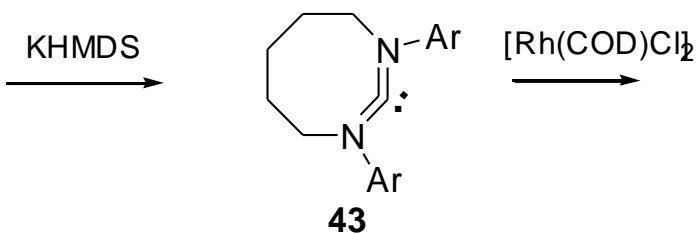

43

$\downarrow \operatorname{Rh}(\mathrm{CO})_{2}(\mathrm{acac})$

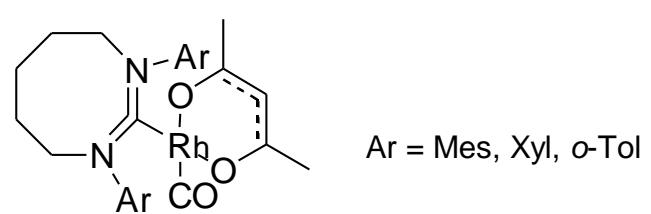

46

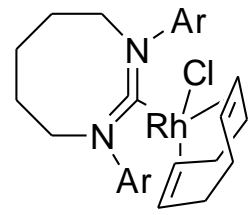

45

$\mathrm{Ar}=0$-tol
590

591

592

593

594

595

596

597

598

\section{Scheme 42}

Key features of these novel RE-NHCs are the extreme steric strain they impose on the metal center and their high electron donor capacity, being some of the most basic NHCs currently available.

5.1.2 Adduct formation. In some cases, the reaction of 1,3-diazepinium salts with alkoxides leads to the addition products (2-alkoxyaminals). In this sense, while the 1,3-dicyclohexyl salt 48 reacts with strong bases affording the expected NHC 49, the corresponding adduct 50 was obtained when the salt was treated with potassium tert-butoxide in toluene (Scheme 43$).{ }^{101}$ 


$$
\text { Cy }
$$

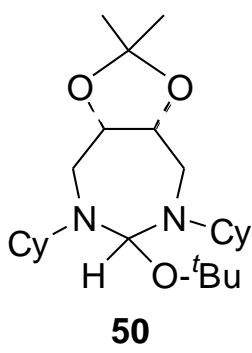

\section{Scheme 43}

Similarly, the adduct (7-dipp)(H)(OMe) $\mathbf{5 1}$ has been obtained by the reaction of equimolar amounts of the salt and NaOMe in absolute THF (Scheme 44). Attempts to obtain the NHC by vacuum thermolysis have failed. ${ }^{107}$<smiles>CON([18OH])C1=[N+]([18OH])CCCC1</smiles>

[(7-Dipp)H][Br]<smiles>COC1N([13CH3])[13CH2]N([18OH])[13CH2]N1[Pb]</smiles>

51<smiles>CC(C)=C(C)C</smiles>

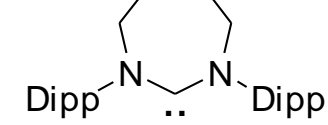

7-Dipp

$$
\text { (7-Dipp)(H) }\left(\mathrm{OCH}_{3}\right)
$$

Dipp $=$ diisipropylphenyl

\section{Scheme 44}

\subsection{Catalytic activity}

Cyclic amidinium salts have low Lewis acid character due to the contribution of the mesomeric structure with the positive charge on the C-2 (Scheme 25). These salts have been used as organocatalysts. ${ }^{127-129}$

Wilhelm et al. have reported the application of several cyclic amidinium salts as catalysts in the ring opening of epoxides (Scheme 45)..$^{97}$ They tested four 1,3-diazepinium salts (52-55) and their activity was compared with the imidazolinium salt 56 (Figure 2). While the salt $\mathbf{5 6}$ displayed very low catalytic activity (12\%), diazepinium salts $\mathbf{5 3}$ and $\mathbf{5 5}$ gave the product in $78 \%$ and $99 \%$ yield, respectively.

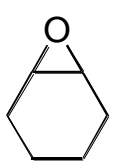

Scheme 45
2 equiv. $\mathrm{PhNH}_{2}$, rt<smiles>O[C@H]1CCCC[C@H]1Pc1ccccc1</smiles>

DCM 


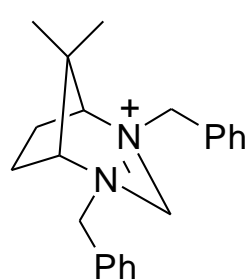

$52\left[3,5-\left(\mathrm{CF}_{3}\right)_{2} \mathrm{C}_{6} \mathrm{H}_{3}\right]_{4} \overline{\mathrm{B}}$

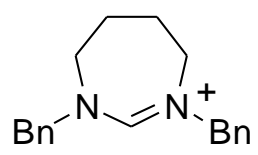

$53\left[3,5-\left(\mathrm{CF}_{3}\right)_{2} \mathrm{C}_{6} \mathrm{H}_{3}\right]_{4} \overline{\mathrm{B}}$

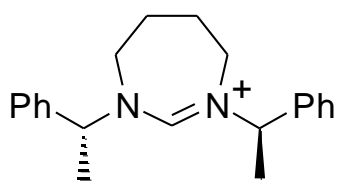

$54\left[3,5-\left(\mathrm{CF}_{3}\right)_{2} \mathrm{C}_{6} \mathrm{H}_{3}\right]_{4} \overline{\mathrm{B}}$

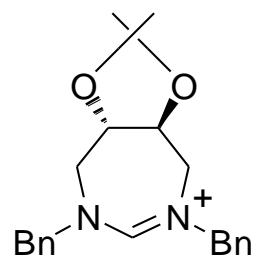

$55\left[3,5-\left(\mathrm{CF}_{3}\right)_{2} \mathrm{C}_{6} \mathrm{H}_{3}\right]_{4} \overline{\mathrm{B}}$

\section{Figure 2}

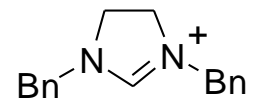

$56\left[3,5-\left(\mathrm{CF}_{3}\right)_{2} \mathrm{C}_{6} \mathrm{H}_{3}\right]_{4} \overline{\mathrm{B}}$

These results were attributed to the special geometry of the 1,3-diazepinium cation which does not allow the planar conformation to be kept, thus the positive charge is less delocalized over the NCN atoms. Instead, there is a better delocalization of the positive charge in the planar $\mathrm{sp}^{2}$-centered imidazoline scaffold in the imidazolinium salts. The camphor-based salt $\mathbf{5 2}$ and the salt $\mathbf{5 4}$, with a larger steric environment around the amidinium unit, gave yields of only $24 \%$ and $38 \%$, respectively.

\section{Acknowledgements}

This work was financially supported by the Universidad de Buenos Aires.

\section{References}

1. Evans, P. A.; Holmes, B. Tetrahedron 1991, 47, 9131

https://doi.org/10.1016/S0040-4020(01)96203-9

2. Prisinzano, T.; Dukat, M.; Law, H.; Slassi, A.; MacLean, N.; DeLannoy, I.; Glennon, R. A. Bioorg. Med. Chem. Lett. 2004, 14, 4697

https://doi.org/10.1016/i.bmcl.2004.06.085

3. Einsiedel, J.; Hübner, H.; Gmeiner, P. Bioorg. Med. Chem. Lett. 2003, 13, 851. https://doi.org/10.1016/S0960-894X(03)00004-0

4. Fujioka, H.; Murai, K.; Ohba, Y.; Hiramatsu, A.; Kita, Y. Tetrahedron Lett. 2005, 46, 2197 and references therein. https://doi.org/10.1016/i.tetlet.2005.02.025

5. Giorgioni, G.; Ambrosini, D.; Vesprini, C.; Hudson, A.; Nasuti, C.; Di Stefano, A.; Sozio, P.; Ciampi, O.; Costa, B.; Martini, C.; Carrieri, A.; Carbonara, G.; Enzensperger, C.; Pigini, M. Bioorg. Med. Chem. 2010, $18,7085$. https://doi.org/10.1016/i.bmc.2010.08.005

6. Wrobel, T. M.; Kosokowska, U.; Kaczor, A. A.; Andrzejczuk, S.; Karczmarzyk, Z.; Wysocki, W.; UrbanczykLipkowska, Z.; Morawiak, M.; Matosiuk, D. Molecules 2015, 20, 14761. 
https://doi.org/10.3390/molecules200814761

7. Hu, C.; Li, X.; Wang, W.; Zhang, L.; Tao, L.; Dong, X.; Sheng, R.; Yang, B.; Hu, Y. Bioorg. \& Med. Chem. 2011, 19, 5455. https://doi.org/10.1016/i.bmc2011.07.050

8. McFarland, J.W.; Howes, H. L. J. Med. Chem. 1969, 12, 1079. https://doi.org/10.1021/im00306a024

9. Weinhardt, K.; Wallach, M. B.; March, M. J. Med. Chem. 1985, 28, 694. https://doi.org/10.1021/im00383a002

10. Langis, A. L.; Pilkington, C. A. U. S. Patent, 3126 381, 1963. Chem. Abstr. 1964, 60, 14517.

11. De Carvalho, G. S; Dias, R. M.; Pavan, F. R.; Leite, C. Q.; Silva, V. L.; Diniz, C. G.; de Paula, D, T.; Coimbra E. S.; Retailleau, P.; da Silva, A. D. Med. Chem. 2013, 9, 351. https://doi.org/10.2174/1573406411309030005

12. Chen, J.-J.; Wang, Z.; Lu, Y.; Dalton, J. T.; Miller, D. D.; Li. W. Bioorg. Med. Chem. Lett. 2008, 18, 3183. https://doi.org/10.1016/i.bmcl.2008.04.073

13. Dunbar, P.G.; Durant, G.J.; Rho, T. J. Med. Chem. 1994, 37, 2774. https://doi.org/10.1021/jm00043a016

14. Messer, W.S.; Abuh, Y.F.; Liu, Y.; Periyasamy, S.; Ngur, D.O.; Edgar, M.A.N.; El Assadi, A. A.; Sbeih, S.; Dunbar, P.; Nagy, P. J. Med. Chem. 1997, 40, 1230.

https://doi.org/10.1021/jm960467d

15. Illuminati, G.; Mandolini, L.; Acc. Chem. Res. 1981, 14, 95. https://doi.org/10.1021/ar00064a001

16. Yet, L.; Chem. Rev. 2000, 100, 2963. https://doi.org/1021/cr990407q

17. Hoberg, J. O.; Tetrahedron 1998, 54, 12631. https://doi.org/10.1016/50040-4020(98)00596-1

18. Evans, P. A.; Holmes, A. B. Tetrahedron 1991, 47, 9131. https://doi.org/10.1016/50040-4020(01)96203-9

19. Appukkuttan, P.; Dehaen, W.; Van der Eycken, E. Org. Lett. 2005, 7, 2723. https://doi.org/10.1021/ol050806

20. Appukkuttan, P.; Dehaen, W.; Van der Eycken, E. Chem. Eur. J. 2007, 13, 6452. https://doi.org/10.1002/chem.200700177

21. Galli, C.; Illuminati, G.; Mandolini, L.; Tamborra, P. J. Am. Chem. Soc. 1977, 99, 2591. https://doi.org/10.1021/ja00450a031

22. Faust, J.A.; Mori, A.; Sahyun, M. J. Am. Chem. Soc. 1959, 81, 2214. https://doi.org/10.1021/ja01518a051

23. Faust, J.; Sahgun, M. U.S. Patent 2953 565, 1960. Chem. Abstr. 1961 ,55, 7449.

24. Wite, A. C.; Black, R. M. Ger. Offen. 2257 784, 1972. Chem. Abstr. 1973, 79,78833z.

25. Sterling Drug Ind., Brit. 1230 347, 1971. Chem. Abstr. 1972, 75, 49154r.

26. Krezel, I. Pharmazie 1998, 53, 614.

27. Nguyen, K. T.; Claiborne, C. F.; McCauley, J. A.; Libby, B. E.; Claremon, D. C.; Bednar, R. A.; Mosser, S. D.; Gaul, S. L.; Connolly, T. M.; Condra, C. L.; Bednar, B.; Stump, G. L.; Lynch, J. L.; Koblan, K. S.; Liverton, N. J. Bioorg. Med. Chem. Lett. 2007,17, 3997. https://doi.org/10.1016/i.bmcl.2007.04.084

28. Einsiedel, J.; Hubner, H.; Gmeiner, P. Bioorg. Med. Chem. Lett. 2003, 13, 851. 
https://doi.org/10.1016/50960-894X(03)00004-0

29. Plate, R.; Jans, C. G. J. M.; Plaum, M. J. M.; de Boer; T. Bioorg. \& Med. Chem. 2002, 10, 1143. https://doi.org/10.1016/S0968-0896(01)00379-0

30. Bünger, J.; Krutmann, J. U.S. Patent 7981899 B2, 2011. Chem. Abstr. 2003, 139, 296563.

31. Ramirez, M. A. Ph. D. Thesis, Universidad de Buenos Aires, Buenos Aires, 2014.

32. Ramirez, M. A.; Ortiz, G. M.; Salerno, A.; Perillo, I. A.; Blanco, M. M. Tetrahedron Lett. 2012, 53, 1367. https://doi.org/10.1016/i.tetlet.2012.01.009

33. Hedrera, M. E.; Perillo, I. A. J. Heterocycl. Chem. 2000, 37, 1431.

https://doi.org/10.1002/ihet.5570370605

34. Pandit, U. K.; Bieraugel, H. J. C. S. Chem. Commun. 1979, 117.

https://doi.org/10.1039/C39790000117

35. Hedrera, M. E. Ph. D. Thesis, Universidad de Buenos Aires, 2000.

36. Hedrera, M. E.; Perillo, I. A.; Fernandez, B. J. Heterocyclic Chem. 2001, 38, 895. https://doi.org/10.1002/jhet.5570380413

37. Singh, K.; Singh, H. In Advances in Heterocyclic Chemistry. Katritzky, A. R. Editor. Elsevier:Oxford, 2006; Vol. 91; pp 159-188.

38. Mathew, R. G.; Drummond, J. T. Chem. Rev. 1990, 90, 1275.

https://doi.org/10.1021/cr00105a010

39. Pandit, U. K.; Bieraugel, H. J. Chem. Soc., Chem. Commun. 1979, 117.

https://doi.org/10.1039/C39790000117

40. Bierugel, H.; Plemp, R.; Hiemstra H. C.; Pandir, U. K. Tetrahedron 1983, 39, 3971.

https://doi.org/10.1016/S0040-4020(01)90903-2

41. Zhang, Y.; Li, D.; Xya, C. Guo, W. Heterocycles 2005, 65, 2893.

https://doi.org/10.3987/COM-05-10528

42. Anderson, M. W., Jones, R. C. F.; Saunders, J. J. Chem. Soc. Commun. 1982, 282.

https://doi.org/10.1039/C39820000282

43. Anderson, M. W., Jones, R. C. F.; Saunders, J. J. Chem. Soc. Perkin Trans. I 1986, 1995. https://doi.org/10.1039/P19860001995

44. Benkovic, S. J.; Bullard, W. P.; Benkovic, P. A. J. Am. Chem. Soc. 1972, 94, 7542. https://doi.org/10.1021/ja00776a043

45. Garcia, M. B.; Zani, M.; Perillo, I.; Orelli, L. Heterocycles 2004, 63, 2557. https://doi.org/10.3987/COM-04-10191

46. Salerno, A.; Ceriani, V.; Perillo, I. A. J. Heterocycl. Chem. 1997, 34, 709. https://doi.org/10.1002/jhet.5570340302

47. Nyce, G. W.; Glauser, T.; Connor, E. F.; Mock, A.; Waymouth, R. M.; Hedrick, J. L. J. Am. Chem. Soc. 2003, 125, 3046. https://doi.org/10.1021/ja021084+

48. Ozdemir, I.; Yigit, M.; Cetinkaya, E.; Cetinkaya,B. Heterocycles 2006, 68,1371. https://doi.org/10.3987/COM-06-10731

49. Bappert, E.; Helmchen, G. Synlett 2004, 1789. https://doi.org/10.1055/s-2004-829548

50. Berger, J.; Nestmann, C.; Neuman, R.; Ruestig, R. Tenside Deterg. 1992, $17,79$.

51. Clavier, H.; Boulanger, L.; Audic, N.; Toupet, L.; Mauduit, M.; Guillemein, J.-C. Chem. Commun. 2004, 1224. 
https://doi.org/10.1039/B402368D

52. Zhou, H.-Y.; Campbell, E. J.; Nguyen, S.-B. T. Org. Lett. 2001, 3, 2229.

https://doi.org/10.1021/ol0161110

53. Jurčík, V.; Wilhelm, R. Org. Biomol. Chem. 2005, 3, 239.

https://doi.org/10.1039/b415023f

54. Oxley, P.; Short, W. F. J. Chem. Soc. 1947, 497.

https://doi.org/10.1039/JR9470000497

55. Johnson, R. N.; Woodburn, H. M. J. Org. Chem. 1962, 27, 3958.

https://doi.org/10.1021/j001058a048

56. Teulon, J. M. Eur. Pat. Appl. EP 0,070,779, 1983; Chem. Abstr. 1983, 99, 10524g.

57. Bailey, D. M.; DeGrazia, C. G.; Wood, D.; Siggins, J. J. Med. Chem. 1974, 17, 702. https://doi.org/10.1021/im00253a009

58. Forsberg, J. H.; Spaziano, V. T.; Balasubramanian, T. M.; Liu, G. K.; Kinsley, S. A.; Duckworth, C. A.; Poteruca, J. J.; Brown, P. S.; Milller. J. L. J.Org. Chem. 1987, 52, 1017.

https://doi.org/10.1021/jo00382a009

59. White, A. C.; Black, R. M. U.S. Patent 3926 994, 1975; Chem. Abstr. 1976, 85, 21505p.

60. White, A. C.; Black, R. M. U.S. Patent 3996 207, 1976; Chem. Abstr. 1976, 85, 21505p.

61. Miller, G. A.; Pridgen, L. N. U.S. Patent 4428 948, 1984; Chem. Abstr. 1984, 100, 174813.

62. Oxley, P.; Short, F. J. Chem. Soc. 1950, 859.

https://doi.org/10.1039/JR9500000859.

63. Desmarchelier, J. M.; Evans, N. A.; Evans, R. F.; Johns, R. B. J. Chem. 1968, 21, 257. https://doi.org/10.1071/CH9680257

64. Arens, J. U.S. Patent 2813 862, 1957; Chem. Abstr. 1958, 52, 8212.

65. Mirskova, A. N.; Seredkina, S. G.; Kalikhman, I. D.; Bannikova, O.B.; Voronkov, M. G. Russ. Chem. Bull. 1989, 38, 815.

https://doi.org/10.1007/BF00953297

66. Papadopoulos, E. P.; George, B. J. Org. Chem. 1977,42, 2530.

https://doi.org/10.1021/j000434a049

67. Rudnichenko, A. V.; Shermolovich, Y. G. Synt. Commun. 2007, 37, 459. https://doi.org/10.1080/00397910601039192

68. Sereda, O.; Clemens, N.; Heckel, T.; Wilhelm, R. Beilstein J. Org. Chem. 2012, 8, 1798. https://doi.org/10.3762/bjoc.8.205

69. Lentzen G. ; Thorsten, N.; T. W.O. Patent 2010006792 A1, 2010; Chem. Abstr. 2010, 152, 192140.

70. Hagen, H.; Becker, F.; Niemeyer, J. Ger Offen. 2016 692, 1971; Chem. Abstr. 1972, 76, 25299m.

71. Hagen, H.; Niemeyer, J. U.S. Patent 3776 910, 1973; Chem. Abstr. 1974, 80, 82995s.

72. Bieraugel, H.; Plemp, R.; Hiemstra, H. C.; Pandit, U. K. Tetrahedron 1983, 39, 3971. https://doi.org/10.1016/S0040-4020(01)90903-2

73. Simion, C.; Gherase, D.; Sima, S.; Simion, A. M. Compt. Rend. Chim. 2015, 18, 611. https://doi.org/10.1016/j.crci.2014.12.006

74. Perillo, I. A.; Fernandez, B.; Lamdan, S. J. C. S. Perkin II, 1977, 2068. https://doi.org/10.1039/P29770002068

75. Diaz, J. E.; Bisceglia, J. A.; Mollo, M. C.; Orelli, L. R. Tetrahedron Lett. 2011, 52, 1895. https://doi.org/10.1016/i.tetlet.2011.02.042

76. Hedrera, M. E.; Lopez, J.; Niemevz, F.; Salerno, A. Perillo ,I. Trends in Organic Chemistry 2008, 12, 61. 
77. Ramirez, M; Corona, M; Blanco, M; Perillo, I.; Porcal, W.; Salerno, A. Tet. Lett. 2010, 51, 5000. https://doi.org/10.1016/i.tetlet.2010.07.075

78. Orelli, L. R.; Niemevz, F.; Garcia, M. B.; Perillo, I. A. J. Heterocycl. Chem. 1999, 36, 105 and references therein.

https://doi.org/10.1002/jhet.5570360116

79. Orelli, L. R: Garcia, M. B.; Perillo, I. A. Heterocycles 2000, 53, 2437. https://doi.org/10.3987/COM-00-9018

80. Perillo, I. A.; Caterina, M. C.; Lopez, J.; Salerno, A. Synthesis 2004, 6, 851 and references therein. https://doi.org/10.1055/s-2004-816011

81. Garcia, M. B.; Torres, R. A. and Orelli, L. R. Tetrahedron Lett. 2006, 47, 4857. https://doi.org/10.1016/i.tetlet.2006.05.042

82. Diaz, J. E.; Gruber, N.; Orelli, L. R. Tetrahedron Lett. 2011, 52, 6443. https://doi.org/10.1016/i.tetlet.2011.09.097

83. Microwaves in Organic Synthesis. Loupy, A. Ed.; Wiley-VCH: Weinheim, 2002.

84. Kappe, C. O.; Dallinger, D. Nat. Rev. Drug. Discovery 2006, 5, 51. https://doi.org/10.1038/nrd1926

85. Roberts, B. A.; Strauss, C. R. Acc. Chem. Res. 2005, 38, 653. https://doi.org/10.1021/ar040278m

86. Kappe, C. O. Angew. Chem. Int. Ed. 2004, 43, 6250. https://doi.org/10.1002/anie.200400655

87. Kappe, C. O.; Dallinger, D. Mol. Divers 2009, 13, 71. https://doi.org/10.1007/s11030-009-9138-8

88. Fernandez, B.; Perillo, I.; Lamdan, S. J. Chem. Soc., Perkin Trans. II 1978, 545. https://doi.org/10.1039/P29780000545

89. Fernandez, B.; Reverdito, A. M.; Paolucci, G.; Perillo, I. J. Heterocycl. Chem. 1987, 24, 1771. https://doi.org/10.1002/jhet.5570240642

90. Salerno, A.; Ceriani, V.; Perillo, I. A. J. Heterocycl. Chem. 1992, 29, 1725. https://doi.org/10.1002/jhet.5570290709

91. Reverdito, A.; Orelli, L.; Dal Mado, M.; Perillo, I.; Fernandez, B. J. Heterocycl. Chem. 1991, $28,273$. https://doi.org/10.1002/jhet.5570280212

92. Benhamou, L.; Chardon, E.; Lavigne, G.; Bellemin-Laponnaz, S.; Cesar, V. Chem. Rev. 2011, 111, 2705. https://doi.org/10.1021/cr100328e

93. Saba, S.; Abrescia, M.; Kaloustian, M. K. Tetrahedron Lett. 1991, 32, 5031. https://doi.org/10.1016/s0040-4039(00)93420-8

94. Iglesias, M.; Beetstra, D. J.; Stasch, A.; Horton, P. N.; Hursthouse, M. B.; Coles, S. J.; Cavell, K. J.; Dervisi, A. and Fallis, I, A. Organometallics 2007, 26, 4800. https://doi.org/10.1021/om7004904

95. Özdemir, I.; Gürbüz, N.; Gök, Y.; Çetinkaya, E.; Çetinkaya, B. Synlett 2005, 15, 2394. https://doi.org/10.1055/s-2005-872673

96. Özdemir, I.; Gürbüz, N.; Gök, Y.; Çetinkaya, E.; Çetinkaya, B. Heteroatom Chem. 2008, 82. https://doi.org/10.1002/hc.20415

97. Sereda, O.; Clemens, N.; Heckel, T.; Wilhelm, R. Beilstein J. Org. Chem. 2012, 8, 1798. https://doi.org/10.3762/bjoc.8.205

98. Newman, P. D.; Cavell, K. J.; Kariuki, B. M. Organometallics 2010, 29, 2724. 
828

829

830

831

832

833

834

835

836

837

838

839

840

841

842

843

844

845

846

847

848

849

850

851

852

853

854

855

856

857

858

859

860

861

862

863

864

865

866

867

868

869

870

871

https://doi.org/10.1021/om1002107

99. Newman, P.D.; Cavell, K. J.; Kariuki, B. M. Dalton Trans. 2012, 41, 12395. https://doi.org/10.10397c2dt31475d

100. Schmidt, F.G. W.O. Patent WO2003085050 A2, 2003. Chem. Abstr. 2003, 139, 308394.

101. Iglesias, M.; Beetstra, D. J.; Stasch, A.; Lorton, P. N.; Hursthouse, M. B.; Coles, S. J.; Cavell, K. J.; Dervisi, A.; Fallis, I. A. Organometallics 2007, 26, 4800.

https://doi.org/101021/om7004904

102. Iglesias, M.; Beetstra, D. J.; Knight, J. C.; Ooi, L.-L.; Stasch, A.; Coles, S.; Male, L.; Hursthouse, M. B.; Cavell, K. J.; Dervisi, A.; Fallis, I. A. Organometallics 2008, 27, 3279.

https://doi.org/10.1021/om800179t

103. Karaca, E. O.; Accoc, M.; Oz, E.; Altin, S.; Dorcet, V.; Roisnel, T.; Gurbuz, N.; Celic, O.; Bayri, A.; Bruneau, C.; Yasar, S.; Ozdemir, I. J. Coord. Chem. 2017, 1270.

https://doi.org/10.1080/00958972.2017.1287906

104. Dunsford, J. J.; Cavell, K. J.; Kariuki, B. J. Organometallics Chem. 2011, 696, 188.

https://doi.org/10.10167j.jorganchem.2010.08.045

105. Dunsford, J. J.; Cavell, K. J. Dalton Trans. 2011, 40, 9131.

https://doi.org/10.10397cldt10596e

106. Binobaid, A.; Iglesias, M.; Beetstra, D.J.; Kariuki, B.; Dervisi, Athanasia, Fallis, I. A.; Cavell, K. J. Dalton Trans. 2009, 7099.

https://doi.org/10.10397b909834h

107. Kolychev, E. L.; Portnyagin, I. A; Shuntikov, V. V.; Khrustalev, V. N.; Nechaev, M. S. J. Organometallic Chem. 2009, 694, 2454. https://doi.org/10.1016/i.jorganchem.2009.03.014

108. Kolychev, E. L.; Sachenco, A. F.; Dzhevakov, P. B.; Bush, A. A.; Shuntikov, V. V.; Khrustalev, V. N.; Nechaev, M. S. Dalton Trans. 2013, 42, 6859.

https://doi.org/10.1039/c3dt32860k

109. Dunsford, J. J.; Tromp, D. S.; Cavell, K. J.; Elsevier, C. J.; Kariuki, B. M. Dalton Trans. 2013, 7318. https://doi.org/10.10397c2dt32823b

110. Lu, W. Y.; Cavell, K. J.; Wixey, J. S.; Kariuki, B. Organometallics 2011, 30, 5649. https://doi.org/10.1021/om200467x

111. Grossmann, A.; Enders, D. Angew. Chem. Int. Ed. 2012, 51, 314.

https://doi.org/10.1002/anie.201105415

112. Clavier, H.; Nolan, S. P. Chem Commun. 2010, 46, 841.

https://doi.org/101039.b922984a

113. Diez-Gonzalez, S.; Marion, N.; Nolan, S. P. Chem. Rev. 2009, 109, 3612.

https://doi.org/10.1021/cr900074m

114. Samojlowicz, C.; Bieniek, M.; Grela, K. Chem. Rev. 2009, 109, 3708.

https://doi.org/10.1021/cr800524f

115. Lin, J. C. Y.; Huang, R. T. W.; Lee, C. S.; Bhattacharyya, A.; Hwang, W. S.; Lin, I. J. B. Chem. Rev. 2009, 109, 3561.

https://doi.org/10.1021/cr8005153

116. Enders, D.; Niemeier, O.; Henseler, A. Chem. Rev. 2007, 107, 5606.

https://doi.org/10.102/cr068372z

117. Marion, N.; Diez-González, S.; Nolan, S.P. Angew. Chem. Int. Ed. 2007, 46, 2988. 
872

873

874

875

876

877

878

879

880

881

882

883

884

885

886

887

888

889

890

891

892

893

894

895

896

897

898

899

900

901

902

903

904

905

906

907

https://doi.org/10.1002/anie.200603380

118. Fevre, M.; Pinaud, J.; Gnanou, Y.; Vignolle, J.; Taton, D. Chem. Soc. Rev. 2013, 2142. https://doi.org/10.1039/c2cs35383k

119. Bugaut, X.; Glorius, F. Chem. Soc. Rev. 2012, 41, 3511.

120. Dröge, T.; Glorius, F. Angew. Chem. Int. Ed. 2010, 49, 6940.

https://doi.org/10.1002/anie.201001865

121. Iglesias, M.; Beetstra, D. J.; Kariuki, B.; Cavell, K. J.; Dervisi, A.; Fallis, I. A. Eur. J. Inorg. Chem. 2009, 1913.

https://doi.org/10.1002/ejic.200801179

122. Akkoç, S.; Gök, Y.; Akkurt, M.; Tahir, M. N. J. Iran. Chem. Soc. 2014, 11, 1767.

https://doi.org/10.1007/s13738-014-0449-z

123. Dunsford, J. J.; Cavell, K. J.; Kariuki, B. Organometallics 2012, 31, 4118.

https://doi.org/10.1021/om300351s

124. Newman, P.; Cavell, K. J.; Kariuki, M. Dalton Trans. 2012, 41, 12395.

https://doi.org/10.1039/c2dt31475d

125. Hauwert, P.; Dunsford, J. J.; Tromp, D. S.; Weigand, J. J.; Lutz, M.; Cavell, K. J.; Elsevier, C. J.

Organometallics 2013, 32, 131.

https://doi.org/10.1021/om300930w

126. Dröge, T.; Glorius, F. Angew. Chem. Int. Ed. 2010, 49, 6940.

https://doi.org/10.1002/anie.201001865

127. Jurčík, V.; Wilhelm, R. Tetrahedron Asymmetry 2006, 17, 801.

https://doi.org/10.10167j.tetasy.2006.02.021

128. Zhou, H.; Campbell, E. J.; Nguyen S. T. Org. Lett. 2001, 3, 2229.

https://doi.org/10.1021/ol0161110

129. Jurčík, V.; Wilhelm, R. Org. Biomolecular Chem. 2005, 239.

https://doi.org/10.10397b415023f

\section{Authors Biographies}

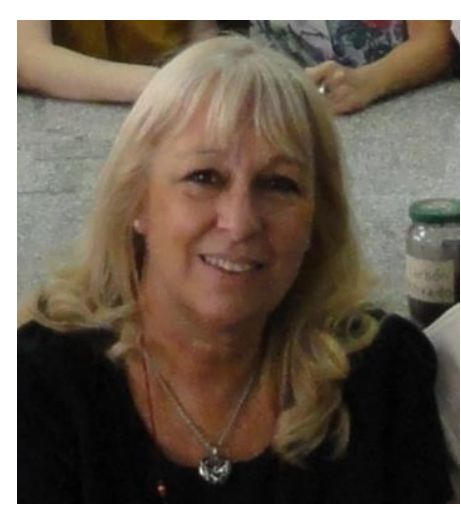

Prof. Alejandra Salerno graduated from Universidad de Buenos Aires (Biochemistry) in 1983. She obtained her PhD Degree in Biochemistry under the supervision of Prof. Isabel Perillo in 1999. Her PhD work was focused on the synthesis and study of imidazole derivatives. Her main research interests are the drug design, synthesis and biological study of nitrogen heterocycles with biological activities. She is an Associate Professor at the Department of Organic Chemistry 


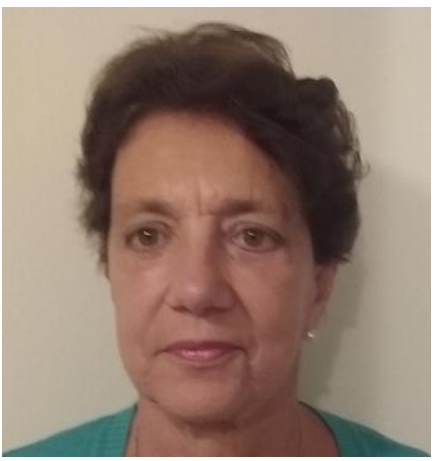

Prof. Isabel Amalia Perillo was born in Buenos Aires, Argentina, in 1942. She studied at the Buenos Aires University receiving a degree in Biochemistry in 1965 and PhD in Biochemistry under the supervision of Dr. Samuel Lamdan. Her research interests include organic and heterocyclic chemistry, in particular synthesis and chemical properties of nitrogen heterocyclic compounds. She has published about 100 research articles related on these subjects. Since 1976 she has served on the Faculty of Pharmacy and Biochemistry of the Buenos Aires University as Full Professor of Organic Chemistry. She is currently Active Emeritus Professor of Organic Chemistry at the Department Organic Chemistry.

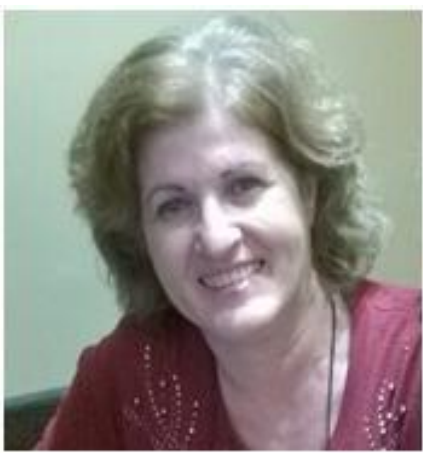

María Cristina Caterina studied at the Universidad de Buenos Aires, Argentina, receiving degree in Biochemistry in 1984. She is currently a PhD candidate in Biochemistry under the supervision of Dr. Alejandra Salerno. Her research includes the synthesis and study of dinitrogen heterocyclic compound imidazole derivatives. 